\title{
LIMITING GORPORATE DIRECTORS' LIABILITY: DELAWARE'S SECTION 102(b)(7) AND THE EROSION OF THE DIRECTORS' DUTY OF GARE
}

\author{
Thomas C. LeE†
}

\section{INTRODUCTION}

The corporate directors' duty of care ${ }^{1}$ ideally plays a crucial role in corporate management. From the shareholders' perspective, that duty theoretically represents an emblem of their ownership of, and ultimate control over, the corporation. It aids shareholders in monitoring those who manage the corporation for the shareholders' benefit, while also allowing the courts to scrutinize unreasonable managerial behavior. In reality, however, such an idealistic perspective is naive as the duty of care has, in fact, led a "twilight existence."2 Indeed, many have

† A.A. 1981, New York University; B.A. 1983, Columbia University; J.D. Candidate 1988, University of Pennsylvania.

1 The duty of care is phrased most often in terms of negligence:

(a) A director shall discharge his duties as a director, including his duties as a member of a committee:

(1) in good faith;

(2) with the care an ordinarily prudent person in a like position would exercise under similar circumstances; and

(3) in a manner he reasonably believes to be in the best interests of the corporation.

Revised Model. Business CoRp. Act $\S 8.30$ (a) (1984) [hereinafter Model Act]; see, e.g., CAL. CoRP. CODE § 309(a) (West 1977) ("with such care, including reasonable inquiry, as an ordinarily prudent person in a like position would use under similar circumstances"); N.Y. Bus. CoRP. LAW $\S 717$ (McKinney 1986) ("with that degree of care which an ordinarily prudent person in a like position would use under similar circumstances"); R.I. GEN. LAwS § 7-1.1-33 (1985) ("with such care as an ordinarily prudent person in like position would use under the circumstances").

${ }^{2}$ Goffee, Litigation and Corporate Governance: An Essay on Steering Between Scylla and Charybdis, 52 Geo. WASH. L. REv. 789, 796 (1984). For recent discussions of the duty of care, see generally Cohn, Demise of the Director's Duty of Care: Judicial Avoidance of Standards and Sanctions Through the Business Judgment Rule, 62 Tex. L. Rev. 591 (1983) (providing a general discussion of duty of care litigation and analyzing the general judicial hesitation in finding breaches of such duty); Conard, A Behavioral Analysis of Directors' Liability for Negligence, 1972 DUKE L.J. 895 (analyzing the behavior of directors as influenced by the existence of directors' liability rules); Fischel \& Bradley, The Role of Liability Rules and the Derivative Suit in Corporate Law: A Theoretical and Empirical Analysis, 71 CoRNELL L. REv. 261 (1986) (discussing proposals which seek to expand the duties of care and loyalty and analyzing the role liability rules play in assuring contractual performance in publicly-held corporations); Goldstein, The Relationship Between the Model Business Corporation Act and the Principles of Corporate Governance: Analysis and Rec- 
argued that the duty of care has been a doctrine whose bark is worse than its bite, as evidenced by the very few cases finding liability solely on negligence grounds. ${ }^{3}$

Recently, a reawakening of the duty of care has broken the relative tranquility of corporate America. That awakening has brought about what many have called a "crisis," real or imagined. ${ }^{4}$ The talk of crisis has been sparked by recent well-publicized cases finding directors in breach of their duty of care, ${ }^{5}$ and by a concurrent violent swing in

ommendations, 52 GEo. WASH. L. REv. 501 (1984) (discussing sections of various model acts, as well as other provisions relating to the duty of care); Hinsey, Business Judgment and the American Law Institute's Corporate Governance Project: The Rule, the Doctrine, and the Reality, 52 GEO. WASH. L. REv. 609 (1984) (discussing the duty of care in relation to the business judgment rule); Kennedy, The Standard of Responsibility for Directors, 52 Geo. WAsH. L. REv. 624 (1984) (analyzing the duty of care as provided for in the corporate governance project of the American Law Institute); Scott, The Role of Preconceptions in Policy Analysis in Law: A Response to Fischel and Bradley, 71 CoRnell L. REv. 299 (1986) (emphasizing the distinction between the fiduciary duty of loyalty and the fiduciary duty of care in the context of corporate governance); Special Project: Director and Officer Liability, 40 VAND. L. Rev. 599 (1987) [hereinafter Special Project] (providing a thorough analysis of current developments involving the duty of care, the duty of loyalty, and the business judgment rule, as well as a discussion of the current crisis in directors' and officers' liability insurance).

${ }^{3}$ Commentators have pointed out the paucity of cases in which a director's negligent actions, uncomplicated by any showings of bad faith or self-dealing, formed the basis of a finding of personal liability. See W. KLEIN \& J. CoffeE, JR., Business Organization AND Finance 140 (2d ed. 1986) (noting that "reported cases in which liability has in fact been imposed are remarkably few and generally have involved instances in which corporate officials were suspiciously inattentive to an impending disaster that the court believed would have been obvious to a minimally attentive person"); Bishop, Sitting Ducks and Decoy Ducks: New Trends in the Indemnification of Corporate Directors and Officers, 77 Y ALE L.J. 1078, 1100 (1968) (commenting that, of the cases finding liability, "none . . . carries real conviction"); Cohn, supra note 2, at 593 (discussing the judicial reluctance to apply negligence standards against well-intentioned directors and officers not motivated by self-enrichment); Kennedy, supra note 2, at 631 (stating that "it has been commonplace that most decisions in which directors have been held liable on due-care grounds also involved either dishonesty or egregious inattention"). Commentators often have cited the business judgment rule, coupled with extreme judicial hesitance in granting large damage awards for unreasonable, but "honest," errors of judgment, as the cause for the scarcity of cases finding breach of duty of care liability. See Cohn, supra note 2, at 593-95. Other commentators have cited additional reasons, such as the role of settlements. See, e.g., Coffee, supra note 2, at 796 .

- See, e.g., Comment, Statutory Limitations on Directors' Liability in Delaware: A New Look at Conflicts of Interest and the Business Judgment Rule, 24 HARv. J. ON LEgIS. 527, 529 (1986) (noting that the stated purpose of DEL. Code ANN. tit. 8, $\S 102(b)(7)$ (Supp. 1986) is "to help alleviate the perceived crisis in the availability of liability insurance for directors"); see also Baum, The Job Nobody Wants, Bus. WK., Sept. 8, 1986, at 56 (noting the unpopularity of directorships and outlining the problems that are causing directors to step down).

- See Hanson Trust PLC v. ML SCM Acquisition Inc., 781 F.2d 264 (2d Cir. 1986); Smith v. Van Gorkom, 488 A.2d 858 (Del. 1985); Francis v. United Jersey Bank, 87 N.J. 15, 432 A.2d 814 (1981). For a discussion of these three cases, see infra 
the insurance markets making directors' and officers' liability insurance ("D\&O insurance") painfully expensive or simply unavailable. ${ }^{6}$ Many qualified directors, fearing potentially devastating personal loss ${ }^{7}$ in exchange for "modest" directorship fees, ${ }^{8}$ have fled corporate boardrooms in search of greener and safer pastures. Especially quick to flee have been outside directors ${ }^{9}$ who do not have as much at stake in the company as do inside directors. These developments, in turn, have sent lobbyists scurrying to state legislative bodies seeking statutory remedies for their woes. The legislative acquiescence to the cries of corporate lobbyists is the focus of this Comment.

Delaware, for example, has recently added a new provision to its corporations code enabling corporations to insert in their certificates of incorporation a provision limiting or eliminating ${ }^{10}$ directors' liability for breach of their duty of care. ${ }^{11}$ Other states have followed suit and

notes 30-65 and accompanying text.

'See Baum, supra note 4, at 56; Hinsey, Directors' and Officers' Insurance: A Status Report, 18-2 INST. ON SEC. REg. 179 (1986) (comparing D\&O insurance market for September 1984 and September 1986); Lewin, Director Insurance Drying Up, N.Y. Times, Mar. 7, 1986, at D1, col. 2; Business Struggling to Adapt as Insurance Crisis Spreads, Wall St. J., Jan. 21, 1986, at 31; Hertzberg, Insurers Beginning to Refuse Coverage on Directors, Officers in Takeover Cases, Wall St. J., Jan. 20, 1986, at 3, col. 2; Hilder, Risky Business: Liability Insurance Is Difficult to Find Now for Directors, Officers, Wall St. J., July 10, 1985, at 1, col. 6.

See Special Project, supra note 2, at 601-03 (noting that the increase in litigation involving directors has led to unprecedented damage awards and high costs).

$B$ Directorship fees can range anywhere from zero to handsome five-figure sums, along with a variety of perquisites and options. As an example, in 1986, Allied-Signal offered a flat fee of $\$ 45,000$ a year, two personal insurance policies, lifetime retirement benefits, and a one-time grant of 1,500 shares. Some well-known "professional directors" have been known to earn six-figure directorship-related incomes. See Baum, "Professional" Directors: So Many Boards, So Little Time, Bus. Wk., Sept. 8, 1986, at 59 .

- An outside director generally is defined as "one who is neither an officer nor an employee of the corporation . . . . There are some exceptions where, because of special knowledge or experience, a person should not be classified as an outside director . . . ." Rowen v. Le Mars Mut. Ins. Co., 282 N.W.2d 639, 652 (Iowa 1979).

10 For the sake of convenience, this Comment will refer to these provisions as either "liability-limiting" or "liability-eliminating" provisions. These labels are interchangeable and should not be construed to cloud the fact that this Comment is dealing with an enabling provision which allows either liability limitation or elimination.

11 Del. Cone ANN. tit. 8, \& 102(b)(7) (Supp. 1986) provides:

(b) In addition to the matters required to be set forth in the certificate of incorporation by subsection (a) of this section, the certificate of incorporation may also contain any or all of the following matters:

(7) $\Lambda$ provision eliminating or limiting the personal liability of a director to the corporation or its stockholders for monetary damages for breach of fiduciary duty as a director, provided that such provision shall not eliminate or limit the liability of a director: (i) For any breach of the director's duty of loyalty to the corporation or its stockholders; (ii) for acts or omissions not in good faith or which 
enacted similar provisions. ${ }^{12}$ Still others have chosen a different solution: a lower standard of conduct for directors and officers. ${ }^{13}$ The

involve intentional misconduct or a knowing violation of law; (iii) under $\S 174$ of this title; or (iv) for any transaction from which the director derived an improper personal benefit. No such provision shall eliminate or limit the liability of a director for any act or omission occurring prior to the date when such provision becomes effective. All references in this paragraph to a director shall also be deemed to refer to a member of the governing body of a corporation which is not authorized to issue capital stock.

For a comprehensive analysis of the new Delaware law, see generally Veasey, Finkelstein \& Bigler, Delaware Supports Directors with a Three-Legged Stool of Limited Liability, Indemnification, and Insurance, 42 Bus. LAw. 399, 401 (1987) (stating that the Delaware legislature has created "a three-legged stool of director support: implementation of the new legislation limiting director liability, broad indemnification rights (within allowable limits), and a comprehensive plan of insurance (if available)").

${ }_{12}$ See, e.g., 42 Pa. Cons. Stat. AnN. § 8634 (Purdon Supp. 1987); Act effective April 12, 1987, ch. 129, 1987 Ariz. Legis. Serv. 300 (West); Act approved Apr. 14, 1987, ch. 958, 1987 Ark. Legis. Serv. 3096 (Michie); Act approved Jan. 30, 1987, ch. 88, 1987 Kan. Sess. Laws 533; Act approved Feb. 27, 1987, ch. 1, 1987 Mich. Legis. Serv. 1 (West); Act approved Feb. 4, 1987, ch. 35, 1987 N.J. Legis. Serv. 171 (West); Act approved July 23, 1987, ch. 367, 1987 N.Y. Legis. Serv. 631 (McKinney).

is See Fla. STAT. § 607.1645 (1987), reprinted in 3 Corp. Statutes (P-H) 53 (1987) (emphasis added):

(1) A director is not personally liable for monetary damages to the corporation or any other person for any statement, vote, decision, or failure to act, regarding corporate management or policy, by a director, unless: and

(a) The director breached or failed to perform his duties as a director;

(b) The director's breach of, or failure to perform, those duties constitutes:

4. In a proceeding by or in the right of the corporation to procure a judgment in its favor or by or in the right of a shareholder, conscious disregard for the best interest of the corporation, or willful misconduct; . . . .

IND. CoDE ANN. $§ 23-1-35-1$ (West Supp. 1987) (emphasis added) provides:

(a) A director shall, based on the facts then known to the director, discharge the duties as a director, including the director's duties as a member of a committee:

(1) in good faith;

(2) with the care an ordinarily prudent person in a like position would exercise under similar circumstances; and

(3) in a manner the director reasonably believes to be in the best interests of the corporation.

(e) $\Lambda$ director is not liable for any action taken as a director, or any failure to take any action, unless:

(1) the director has breached or failed to perform the duties of the director's office in compliance with this section; and

(2) the breach or failure to perform constitutes willful misconduct or recklessness.

VA. CoDE ANN. § 13.1-690(A) (1985) (emphasis added) provides: "A director shall discharge his duties as a director, including his duties as a member of a committee, in 
American Law Institute ("ALI") has deliberated on this matter and has proposed a novel solution: limiting the liability of directors to "an amount that is not disproportionate to the economic benefits to the defendant for serving the corporation."14

This Comment will focus on the advisability of enabling provisions such as that enacted by Delaware. Part I analyzes the recent developments in duty of care jurisprudence, the D\&O insurance market, and the composition of the boards of corporate America. Part II examines the compensatory and deterrent rationales underlying the duty of care doctrine and concludes that this doctrine serves an important, albeit limited, function in corporate governance. Part III explores the shortcomings of the Delaware-type provisions and contrasts them with alternative approaches. This Comment then concludes by arguing that the

accordance with his good faith business judgment of the best interests of the corporation."

14 American Law Institute, Principles of Corporate Governance: ANALYSIS AND ReCOMmendations $\S 7.17$ (Tent. Draft No. 6, 1986) [hereinafter ALI Drafr No. 6] (emphasis added) provides in pertinent part:

(a) If a failure by a director . . . or an officer . . . to meet the standard of conduct specified in $\S 4.01$ did not

(1) involve a knowing and culpable violation of law; or

(2) enable the defendant, or an associate . . ., to receive an improper benefit to which the defendant, or such associate, was not entitled under Part V; or

(3) show a conscious disregard for the defendant's duty to the corporation under circumstances that threatened serious injury to the corporation; or

(4) constitute a sustained and unexcused pattern of inattention that amounted to an abdication of the defendant's duty to the corporation, damages for the violation should be limited to an amount that is not disproportionate to the economic benefits to the defendant for serving the corporation.

(b) A limitation on damages complying with $\S 7.17$ (a) should be effective if implemented by:

(1) an enabling statute that authorizes the inclusion of a limitation on damages in a corporation's certificate of incorporation; or

(2) a provision in a certificate of incorporation that is adopted by a vote of disinterested shareholders . . . after appropriate disclosure concerning the provision; or

(3) judicial decision, if the court finds that in the circumstances justice so requires because the damages would otherwise be disproportionate under $\$ 7.17(\mathrm{a})$.

(c) Any limitation on damages set forth in the corporation's certificate of incorporation should

(1) require renewal by shareholder vote at periodic intervals and, in the case of a provision not expressly authorized by statute, by annual disinterested shareholder vote; and

(2) not reduce liability with respect to pending actions, or losses incurred prior to its adoption, unless a contrary legislative intent plainly appears. 
Delaware-type legislation is an inappropriate response to the corporate director "crisis," a quick fix solution that may have deleterious effects on corporate governance. Additionally, this Comment offers a proposal for a more tempered solution, one that does not enable the corporation to totally eliminate directors' liability for breach of their duty of care.

\section{The Duty of Care Melee}

The debate surrounding the duty of care has been especially heated in recent years. In order to understand this controversy, it is necessary first to review briefly the subdued history of the duty, then to examine the developments in three areas that are the focal points of the duty of care melee: 1) the recent cases seemingly putting some "bite" back into the duty; 2) the recent D\&O insurance crisis; and 3) the resulting flight and refusals to serve by directors.

\section{A. A Brief History of the Duty of Care}

In an oft-cited article, Professor Bishop wrote that " $[t]$ he search for cases in which directors of industrial corporations have been held liable in derivative suits for negligence uncomplicated by self-dealing is a search for a very small number of needles in a very large haystack."16 $\mathrm{Up}$ to that point (May 1968), he had found only four such cases. ${ }^{16} \mathrm{~A}$ more recent count (December 1983) brought the total to seven. ${ }^{17}$ By any reckoning, reported cases holding directors liable for purely "honest mistakes" are rare indeed. ${ }^{18}$

One reason for the duty of care doctrine's twilight existence is that its greatest strength is also its greatest weakness: the enormous coverage of its negligence standard. The fact that the number of matters it conceivably might address is indefinitely large has forced courts to eschew its application and to confront the plaintiff with imposing legal hurdles.

15 Bishop, supra note 3, at 1099.

${ }^{16}$ Id. at $1099-1100$ (citing New York Credit Men's Adjustment Bureau v. Weiss, 305 N.Y. 1, 110 N.E.2d 397 (1953); Syracuse Television, Inc. v. Channel 9, Syracuse, 51 Misc. 2d 188, 273 N.Y.S.2d 16 (Sup. Ct. 1966); Glayton v. Farish, 191 Misc. 136, 73 N.Y.S.2d 727 (Sup. Ct. 1947); Selheimer v. Manganese Corp. of Am., 423 Pa. 563, 224 A.2d 634 (1966)).

17 Cohn, supra note 2, at $591 \mathrm{nn} .1-2$. The additional cases are DePinto v. Provident Sec. Life Ins. Co., 374 F.2d 37 (9th Cir.), cert. denied, 389 U.S. 822 (1967); Heit v. Bixby, 276 F. Supp. 217 (E.D. Mo. 1967); Kaplan v. Centex Corp., 284 A.2d 119 (Del. Ch. 1971). The cases discussed infra notes $30-63$ and accompanying text may be further additions to this list.

is One can debate, of course, whether even these cases truly are "uncomplicated by self-dealing," either as a factual matter or as a general proposition that due to structural biases in the director selection process, one can never be confident that directors act with absolute altruism. See R. Glark, Corporate Law $\$ 3.2 .1$ (1986). 
For example, this judicial apprehension is evident in the common law evolution of the corporate directors' standard of care. At first, that standard required a rigorous "degree of care and prudence that men prompted by self-interest generally exercise in their own affairs." 19 A more subjective, situation-specific standard of "an ordinarily prudent person in a like position . . under similar circumstances" now generally prevails, ${ }^{20}$ while Delaware courts have enunciated an ominous standard of "gross negligence."21

Another manifestation of this judicial avoidance is the liberal application of the business judgment rule. ${ }^{22}$ It is well-noted that judges

10 Hun v. Cary, 82 N.Y. 65, 71 (1880) (emphasis added). For a sampling of older cases, see Smith v. Prattville Mfg. Co., 29 Ala. 503 (1857); Gubbins v. Bank of Commerce, 79 Ill. App. 150 (1898); Simon v. Socony-Vacuum Oil Co., 179 Misc. 202, 38 N.Y.S.2d 270 (Sup. Ct. 1942), affd, 267 A.D. 890, 47 N.Y.S.2d 589 (1944); Scott v. De Peyster, 1 Edw. Ch. 513 (N.Y. Ch. 1832); Marshall v. Farmers' \& Mechanics' Sav. Bank, 85 Va. 676, 8 S.E. 586 (1889). As of 1985, the American Law Institute identified four states where this standard still prevailed: Alabama, Mississippi, Nebraska, and Utah. See Principles of Corporate Governance: Analysis and RECOMMENDATIONS § 4.01 reporter's note (Tent. Draft No. 4, 1985) [hereinafter "ALI DRAFT No. 4"]. It should be noted that some earlier case law involving bank directors, such as Hun v. Cary, held such directors to a higher standard of care than directors of ordinary corporations. See W. CARY \& M. EISEnBERG, CASES \& MATERIALS ON CORPORATIONS 523 (5th ed. 1980).

${ }^{20}$ Monfl. ACT, supra note $1, \S 8.30$ (emphasis added). Cases espousing similar standards include Berkman v. Rust Craft Greeting Cards, Inc., 454 F. Supp. 787 (S.D.N.Y. 1978); McLeod v. Lewis-Clark Hotel Co., 66 Idaho 584, 164 P.2d 195 (1945); FMA Acceptance Co. v. Leatherby Ins. Co., 594 P.2d 1332 (Utah 1979).

${ }^{21}$ See Smith v. Van Gorkom, 488 A.2d 858, 873 (Del. 1985); Aronson v. Lewis, 473 A.2d 805, 812 (Del. 1984). This is not meant to suggest that the historical movement to a lower standard of conduct required of directors was so clear-cut or uniform among various jurisdictions. A cursory review of the Decennial Digests, however, should make this evolution readily apparent. One hardly sees cases applying the "in his own affairs" standard nowadays, just as one hardly sees any earlier cases applying the "in a like position under similar circumstances" standard.

${ }_{22}$ For a codification of the business judgment rule, see ALI Draft No. 4, supra note $19, \S 4.01$ (c), which provides:

(c) $A$ director or officer who makes a business judgment in good faith fulfills his duty under this Section if:

(1) he is not interested . . . in the subject of his business judgment;

(2) he is informed with respect to the subject of his business judgment

to the extent he reasonably believes to be appropriate under the circumstances; and

(3) he rationally believes that his business judgment is in the best interests of the corporation.

For a discussion of the business judgment rule, see generally R. GLARK, supra note 18 , $\S 3.4$ (discussing the business judgment rule and how it relates to the duty of care); $\mathrm{H}$. Henn \& J. Alexander, Laws of Corporations $\S 242$ (3d ed. 1983) (defining the business judgment rule as a rule which "sustains corporate transactions and immunizes management from liability where the transaction is within the powers of the corporation (intra vires) and the authority of management, and involves the exercise of due care and compliance with applicable fiduciary duties"); Hinsey, supra note 2, at 602 (analyzing the treatment of the business judgment rule in the standards set forth by the 
are very reluctant to interfere with the business judgments of directors. ${ }^{23}$ An example of this judicial distaste for "hindsight" adjudication of good faith business decisions is Kamin v. American Express Company. ${ }^{24}$ In Kamin, the defendant company had made a disastrous investment in another company, which could have resulted in a capital loss of $\$ 25$ million had the shares in the target company been sold on the open market. Such a sale, however, would have resulted in an $\$ 8$ million tax savings. Instead, the board of directors declared a "special dividend" pursuant to which the shares in the target company would be distributed in kind. ${ }^{25}$ The plaintiff shareholders challenged this distribution. The court, however, declared that '[ $t]$ he directors' room rather than the courtroom is the appropriate forum for thrashing out purely business questions. . . ."26

The Kamin decision is illustrative of the extreme judicial tolerance of "heat of the moment" good faith business decisions. Further, it shows the extent to which the business judgment rule has virtually en-

ALI).

23 See W. Cary \& M. Eisenderg, supra note 19, at 552 (citing Miller v. AT\&T, 507 F.2d 759 (3d Cir. 1974); Selheimer v. Manganese Corp. of Am., 423 Pa. 563, 224 A.2d 634 (1966); Auerbach v. Bennett, 47 N.Y.2d 619, 393 N.E.2d 994, 419 N.Y.S.2d $920(1979))$.

${ }^{24} 86$ Misc. 2d 809, 383 N.Y.S.2d 807 (Sup. Ct.), affd, 54 A.D.2d 654, 387 N.Y.S.2d 993 (1976).

${ }^{25} I d$. at 811,383 N.Y.S.2d at $809-810$.

${ }^{28} I d$. at $812-13,383$ N.Y.S.2d at $810-11$. Moreover, the court bent over backwards to lend legitimacy to the directors' decision at issue by stating:

[The directors] concluded that there were countervailing considerations primarily with respect to the adverse effect such a sale, realizing a loss of $\$ 25,000,000$, would have on the net income figures in the American Express financial statement. Such a reduction of net income would have a serious effect on the market value of the publicly traded American Express stock.

Id. at 814,383 N.Y.S.2d at 811 (emphasis added). In other words, the directors may make an adverse financial decision, in Kamin the foregoing of an $\$ 8$ million tax savings, to "save face" in the open market.

One can certainly understand why the directors of a high-profile financial company would not want to proclaim in the open market that they had made a terrible investment decision. But the court's "serious effect on the market value" line of reasoning is susceptible to the "slippery slope" argument. For example, could a court excuse the nondisclosure of management fraud because that would adversely effect the company's stock prices? Of course, the Kamin court would not have gone that far.

The Kamin decision was wrongly decided because the court did not allow a full development of the facts as to whether a business decision had in fact been made (i.e. a decision comparing the foregone tax savings with the possible decline in the value of the company stocks) before invoking the business judgment rule. The court does intimate, however, that the plaintiffs" objections to the "special dividend" were "carefully considered" by the board of directors, id. at 813,383 N.Y.S.2d at 811 , but this is insufficient to constitute the lack of a "genuine issue of material fact" required to sustain the defendants' pretrial motions. 
gulfed the duty of care doctrine. Commentators, in turn, either have mourned the duty of care in light of these developments, ${ }^{27}$ or have argued to bury it once and for all. ${ }^{28}$ Then came a recent set of cases, the most prominent of which is Smith $v$. Van Gorkom, ${ }^{29}$ which added more fuel to the fire in this duty of care melee.

\section{B. Reawakening the Sleeping Giant: Recent Vigorous Application of the Duty of Care}

Three prominent cases have allegedly reawakened the great, some may say frightening, potential of the duty of care: Francis $v$. United Jersey Bank, ${ }^{30}$ Smith v. Van Gorkom (the Trans Union case), and Hanson Trust PLC v. ML SCM Acquisition Inc. ${ }^{31}$ These cases sent shock waves not only through the boardrooms of corporate America, but also through the halls of state legislatures. ${ }^{32}$ A close examination of these cases, however, reveals that such lobbying efforts were neither imperative nor appropriate.

In Francis, the New Jersey Supreme Court condemned one form of a director's breach of duty that has always met with the strongest judicial disapproval: directorial inactivity ${ }^{33}$ Francis provided the New

${ }^{27}$ See Cohn, supra note 2, at 595; Cox, Compensation, Deterrence, and the Market as Boundaries for Derivative Suit Procedure, 52 GEO. WASH. L. REv. 745, 75863 (1984).

${ }^{28}$ See Scott, Corporate Law and the American Law Institute Corporate Governance Project, 35 STAN. L. REv. 927, 935-37 (1983). For an evaluation of the opposing views, see Coffee, supra note 2.

29 488 A.2d 858 (Del. 1985).

so 87 N.J. 15, 432 A.2d 814 (1981).

31781 F.2d 264 (2d Cir. 1986).

32 See Del. Code ANN. tit. 8, § 102(b)(7) (Supp. 1986) (reproduced supra note 11). Most notably, Gilchrist Sparks III, the chairman of the Corporate Law Section of the Delaware Bar $\Lambda$ ssociation which drafted section 102(b)(7), explicitly cited Trans Union as one major reason for the adoption of the provision. See Sparks III, Delaware's DEO Liability Law: Other States Should Follow Suit, Legal Times, Aug. 18, 1986 , at 10, col. 1 .

ss See generally R. ClaRk, supra note $18, \S 3.4 .1$ (stating that the most common violation of the directorial duty of care is inactivity; that is, the "simple failure . . . to engage in the basic activities of [a director]"). As will be more fully developed, see infra text accompanying notes 189-215, the Delaware liability-limiting provision would either tolerate such socially undesirable behavior or would force the litigant to recharacterize what has always been regarded as an act in breach of the duty of care as one of the enumerated exceptions in the Delaware provision. See supra note 11. The court would most likely require the plaintiff to prove that the inactivity constituted an omission not in good faith or involved intentional misconduct. See DeL. CoDE ANN. tit. $8, \S 102($ b)(7)(ii) (Supp. 1986). Forced to take the latter route, the plaintiff would most likely have a more difficult case to prove. See R. GlaRk, supra note $18, \S 3.4 .1$ (discussing the evidentiary difficulties inherent in a breach of fiduciary duty suit not based upon a negligence standard). 
Jersey Supreme Court with a fascinating fact pattern ${ }^{34}$ as a vehicle for its pronouncement. Plaintiffs were not shareholders, as is typical in such an action, but trustees in bankruptcy; the defendant was the executrix of a deceased director's estate. ${ }^{35}$ The case involved a close corporation with three shareholder-directors. ${ }^{36}$ The deceased director, the widow of the company founder, had been a physically incapacitated, grief-stricken alcoholic who "was not active ... and knew virtually nothing of [the] corporate affairs." The court found the estate liable for the deceased director's negligent failure to attempt to forestall a massive fraud perpetrated by the remaining two directors, her sons, and awarded damages of over $\$ 10$ million. ${ }^{38}$ The court's ruling made it forcefully clear that "[a] director is not an ornament, but an essential component of corporate governance. Consequently, a director cannot protect himself behind a paper shield bearing the motto 'dummy director," "39

Trans Union struck closer to the heart of mainstream corporate boards and immediately prompted an uproar. ${ }^{40}$ Prior to the challenged transaction, the Trans Union Corporation appeared to have an "ideal" board of directors: five inside directors and five prominent outside directors, four of whom were experienced chief executive officers ("CEOs") of comparable-sized companies and one a former dean of a prominent business school. ${ }^{41}$ Van Gorkom, CEO and director of Trans Union, hastily arranged a cash-out merger based on a price that Van Gorkom himself grabbed out of the air, never bothering to read the various crucial documents, and thereafter executed the agreement dur-

34 The Francis fact pattern was not necessarily an unusual one; duty of care cases often involve egregious neglect of office. See, e.g., Bowerman v. Hamner, 250 U.S. 504, 507 (1919) (director never attended a single directors' meeting nor in any matter attempted to inform himself); Platt Corp. v. Platt, 42 Misc. 2d 640, 641, 645, 249 N.Y.S.2d 1, 4, 8 (Sup. Ct. 1964) (out-of-state directors did not attend meetings and otherwise neglected their duties, and one director conceded that he did nothing as a director, believing his position to be "honorary"); Neese v. Brown, 218 Tenn. 686, 68990,405 S.W.2d 577, 579 (1964) (virtual abdication of directors' duty by allowing the president to have one-man control).

ss Francis, 87 N.J. at 23, 432 A.2d at 818.

${ }^{36} I d$. at 20,432 A.2d at 816 .

37 Id. at $26-27,432 \mathrm{~A} .2 \mathrm{~d}$ at $819-20$.

s8 Id. at $21,432 \mathrm{~A} .2 \mathrm{~d}$ at $816-17$.

39 Id. at 34,432 A.2d at 823 .

40 Trans Union has been widely noted, criticized, and explained. For instance, the Delaware Journal of Corporate Law virtually dedicated a whole issue to the case. See Moskin, Trans Union: A Nailed Board, 10 DeL. J. CoRP. L. 405 (1985); Prickett, An Explanation of Trans Union to "Henny-Penny" and Her Friends, 10 DEL. J. CoRP. L. 451 (1985); Schwartz \& Wiles, Trans Union: Neither "New" nor "Bad" Law, 10 Del. J. CoRP. L. 429 (1985); Comment, Mining the Safe Harbor? The Business Judgment Rule After Trans Union, 10 DEL. J. CoRP. L. 545 (1985).

${ }^{41}$ Trans Union, 488 A.2d at 894 (McNeilly, J., dissenting). 
ing a social event for the opening of the Chicago Lyric Opera. ${ }^{42}$

The Delaware Supreme Court hinted at the motive behind Van Gorkom's actions by noting that he was "then approaching 65 years of age and mandatory retirement."43 It then held the directors personally liable for, inter alia, a grossly negligent approval of the hastily-arranged cash-out merger without adequately informing themselves of the terms or the financial bases of the merger. ${ }^{44}$

As evidenced by the majority's painstakingly detailed statement of the facts, ${ }^{45}$ the Delaware Supreme Court appeared to go out of its way to use this case as a vehicle to revitalize the dormant duty of care doctrine. Nevertheless, accepting the majority's version of the facts, Trans Union does not represent an extension of duty of care liability but rather a less forgiving application of it. Indeed, according to one commentator, Trans Union "can be fitted . . . into the mainstream of business judgment rule jurisprudence, with its emphasis not on the merits of the decision made by the directors but on the process by which the decision was made." $\$$

Two other commentators, however, would cast Trans Union as a conspicuous departure from mainstream business judgment rule jurisprudence, arguing that:

[T] $\mathrm{T}$ court's decision may rest on a simple misunderstanding of how the world works....

... [T]he court failed to appreciate that courts are not very good at evaluating a director's business acumen and disciplining his or her lapses. . . .

Another thing the court failed to appreciate is the need to help directors be bold. . . .

The [Trans Union] court's effort to [describe good decision making formally] was wasted. Bad decisions can be made while observing all the prescribed formalities of [Trans

${ }^{42}$ Id. at $865-869$.

43 Id. at 865-66.

14 Id. at 881,884 .

15 The dissent even noted that "[t]he majority opinion reads like an advocate's closing address to a hostile jury." Id. at 893 (McNeilly, J., dissenting).

16 Manning, Reflections and Practical Tips on Life in the Boardroom After Van Gorkom, 41 Bus. LAw. 1, 4 (1985); cf. Schwartz \& Wiles, supra note 40, at 442 ("[T]here appears to be no reported decision prior to Trans Union which holds, solely on the basis of the Board's decision-making process, that a third party merger is invalid as the product of an uninformed business judgment. And to this extent Trans Union breaks new ground."). Schwartz and Wiles also note, however, that if proper procedures are followed so that the board is 'informed,' the court of chancery will ordinarily defer to the directors' business judgment." Id. at 443 . 
Union]; good decisions can be reached without them.

... [It] makes for an odd dichotomy [that the] product of a decision gets a lot of respect, [but] the procedure behind it doesn't. ${ }^{47}$

But much of the above-quoted criticism rings hollow. First, "how the world works" cannot serve as a justification for judicial tolerance. The way "it is" is not necessarily the way it should be. The court may very well have "failed to appreciate," or failed to be blinded by, the fact that business judgments are best left to those in business. But even a cursory review of the history of duty of care jurisprudence shows that courts have been extremely deferential to business judgments, ${ }^{48}$ and it would be sensationalistic to argue that the Trans Union court signalled the end of that deeply-rooted judicial sentiment. Indeed, the same court appeared to have settled back into the deferential mode in three prominent post-Trans Union cases. ${ }^{49}$ Moreover, "assuming . . . as true the [majority's] recitation of the . . facts . . ., the outcome of the case is not so startling."

Second, the commentators' argument that good decisions can be reached without the "formalities of [Trans Union]" ignores the emphasis on process, rather than on product. It may be the reasonable hope of the court that a better informed process will lead to a greater number of better informed decisions. It makes a great deal of sense that courts focus solely on the process because the products are subject to innocent pitfalls of human imperfection in judgment which no court is willing to condemn. Thus, bad decisions reached through bad process will be condemned, while bad decisions reached despite good process will not. Good decisions reached through bad process likewise will be frowned upon, but the plaintiff will not be able to recover anything in these cases because the bad process has not caused any damage. ${ }^{51}$ Furthermore, the process-product distinction is not an "odd dichotomy" at all. It is a fundamental concept in American law. ${ }^{\mathrm{s2}}$

${ }^{47}$ Herzel \& Katz, Smith v. Van Gorkom: The Business of Judging Business Judgment, 41 Bus. LAw. 1187, 1189-90 (1986).

18 See supra notes $22-28$ and accompanying text.

18 See Moran v. Household Int'l, Inc., 500 A.2d 1346 (Del. 1985); Unocal Corp. v. Mesa Petroleum Co., 493 A.2d 946 (Del. 1985); Rosenblatt v. Getty Oil Co. 493 A.2d 929 (Del. 1985). For a discussion of this retrenchment, see Henderson, Olson \& Hatch, Developments Inside the Corporate Boardroom: Functioning Without Insurance or Contractual Protection Against Liability, 18-2 INST. ON SEC. REg. 207, 228250 (1986).

so Manning, supra note 46 , at 3.

81 The causation requirement was strongly stated by Judge Hand in Barnes v. Andrews, 298 F. 614, 619-20 (S.D.N.Y. 1924).

${ }_{B 2}$ That concept is embodied in, most obviously, the due process clause, see U.S. 
Finally, the commentators' argument that courts should encourage directors to be bold risk-takers requires further discussion; ${ }^{53}$ however, in view of the post-Trans Union line of cases, it can no longer be said that the Delaware Supreme Court does not respect the force of that argument or that bold businessmen have not adapted well to the commands of Trans Union. ${ }^{54}$ In sum, Trans Union is not, as many had feared, a monster in corporate law jurisprudence.

In Hanson Trust PLC v. ML SCM Acquisition Inc., the Second Gircuit gave the critics of Trans Union further cause for concern. Hanson Trust appeared to require that directors adhere to an even higher standard of care, and the court seemed concerned more with the product of the decision rather than the process behind it. In Hanson Trust, the directors of a cash tender offer target company adopted several dubious "poison pill" tactics. The directors granted a "white knight" company a seriously undervalued irrevocable lock-up option on "crown jewel" assets; ${ }^{.55}$ a $\$ 1.5$ million engagement fee (a "hello fee"); a $\$ 9$ million breakup fee (a "goodbye fee"), later put into an escrow account for the white knight company's appropriation; and a $\$ 6$ million re-engagement fee (a "hello again fee"). ${ }^{58}$ The board, consisting of three inside and nine independent directors, ${ }^{57}$ conformed much of its behavior to what one commentator has called Trans Union's list of “do's and don'ts." 158 While the court phrased much of its analysis in terms of the process of the board decision, ${ }^{58}$ it still was not satisfied, despite the fact

ConsT. amend. V; U.S. ConsT. amend. XIV, $\S 1$, and in the corporate context, the various proxy regulations, see, e.g., 15 U.S.C. $\$ \S 77 l l l, 78 \mathrm{n}, 79 \mathrm{k}, 80 \mathrm{a}-20,80 \mathrm{a}-25$ (1982 \& Supp. III 1985) (attempting to assure informed participation by shareholders in corporate decisionmaking); 17 C.F.R. $\$ 240.14$ (1987) (same).

s3 See infra notes 136-53 and accompanying text.

st See supra note 49 and accompanying text.

os This device was an irrevocable option granted to the white knight company to purchase the most desirable segments of the target company's business, thereby making the target company less desirable to the hostile tender offer. The target company optioned away two such segments of the business at $\$ 350$ million and $\$ 80$ million. There was evidence that the former segment had a value in the $\$ 420-\$ 550$ million range and that the latter was worth approximately $\$ 90-\$ 110$ million. Thus, the court concluded that the "crown jewels" were undervalued by at least $\$ 70$ million, and at most $\$ 230$ million. See id. at 279-80 \& n.10.

${ }^{B 8} I d$. at $269-70$. These fees were demanded by the white knight so that it would be compensated for offering its protective services whether or not a protective merger with the white knight actually took place.

${ }^{87}$ Id. at 267-68.

${ }^{68}$ Manning, supra note 46, at 3, 8-14 (giving a seven-page listing of Trans Union's "do's and don'ts" in the appendix).

${ }^{68}$ See, e.g., Hanson Trust, 781 F.2d at 274 ("[W]here their "methodologies and procedures' are 'so restricted in scope, so shallow in execution, or otherwise so pro forma or halthearted as to constitute a pretext or a sham,' then inquiry into their acts is not shielded by the business judgment rule.") (quoting Auerbach v. Bennett, 47 N.Y.2d 
that the "actions of the [target company] board [did] not rise to that level of gross negligence found in [Trans Union]."

Despite the harsh-sounding judgment, Hanson Trust should not have triggered legislative action to adopt a Delaware-type provision. One key to the Hanson Trust ruling is the procedural posture of the case: the plaintiffs were appealing the denial of their motion for a preliminary injunction. ${ }^{61}$ This was not an appeal from a judgment on the merits as in Trans Union. The Hanson Trust court was not faced with the dilemma of imposing ruinous personal damages upon the defendant directors for their breach of the duty of care. Moreover, injunctive actions are not within the scope of the Delaware liability-limiting provision. ${ }^{62}$ Thus, even if Delaware law controlled this case, the outcome would not have been different. What the outcome would be on adjudication on the merits under principles announced in Hanson Trust is a question for another day. For purposes of this Comment, Hanson Trust, as it now stands, cannot justify the enactment of a Delawaretype provision.

In light of the preceding discussion it would appear alarmist to cite the cases analyzed or the liability explosion to which they have purportedly contributed as justifications for the adoption of liabilitylimiting provisions. ${ }^{63}$ There must be a more compelling reason. The recent insurance crisis provided exactly that for the proponents of the Delaware-type provision.

\section{The Tail Wagging the Dog: Directorial Liability Limitation and the Insurance Crisis}

The pervasive insurance crisis of this decade has not failed to stir up controversy in the boardrooms of corporate America. Corporations recently have found themselves unable to obtain $\mathrm{D} \& \mathrm{O}$ insurance cover-

$619,634,393$ N.E.2d 994, 1002-03, 419 N.Y.S.2d 920, 929 (1979)).

60 Id. at 275.

61 Id. at 266.

62 Section 102(b)(7) of the Delaware Corporation Code only applies to "monetary damages." See supra note 11.

${ }^{63}$ See Black, Jr. \& Sparks III, Analysis of the 1986 Amendments to the Delaware Corporations Law, 3 Corp. Guide (P-H) 311 (July 29, 1986) (stating that directors' concerns "were heightened by highly publicized lawsuits involving potentially ruinous recoveries"); Sparks III, supra note 32, at 10, col. 2 ("perception [of] directors ... that the courts . . . were increasingly willing to impose potentially staggering personal liability upon directors . . . as in the celebrated Trans Union case"); New Delaware Statute Allows Limits on Director Liability and Modernizes Indemnification Protection, A.B.A. Bus. L. UPDATE, July/Aug. 1986, at 1,1 ("principal problem . . . is the legitimate concern of directors over their exposure to personal liability"). 
age, a dubious form of protection in the first place, ${ }^{64}$ either because premium hikes took on astronomical proportions or because policies simply were not available. ${ }^{65}$ Although almost all would agree that the general insurance crisis is a problem deeply rooted in our society, less agreement exists regarding the causes of this crisis. ${ }^{66}$ Yet, the Delaware legislature and others that have followed suit have chosen to place a Band-Aid reform on a cancerous problem, ignoring the deleterious effects on the rights and expectations of shareholders of our corporations.

Drafters of the Delaware provision have cited the shrinking market for $\mathrm{D} \& \mathrm{O}$ insurance as the "driving force behind the bill." perverse turn of events in the $\mathrm{D} \& \mathrm{O}$ insurance market has frequently been heralded by the press. ${ }^{68}$ By one account, prior to 1985 , D\&O premiums for large companies were often less than $\$ 200,000$ for as much as $\$ 100$ million of coverage. But in less than a year, premiums rose in some cases to $\$ 1$ million for about half that coverage. ${ }^{69}$ A comparison study showed that in September, 1984, D\&O insurance was available for losses not actually indemnified by the corporation, for a term of three years, at a premium rate which rarely exceeded $.25 \%$ of the policy limit. It was a buyer's market. ${ }^{70}$ By contrast, in September 1986, $\mathrm{D} \& \mathrm{O}$ insurance was available only for nonindemnifiable losses, whether or not indemnified in fact, for a term of twelve months, at a premium rate of $5 \%$ of the policy limit, with higher levels demanded in higher-risk industries; ${ }^{71}$ indeed, it was a seller's market. Furthermore, additional restrictions and exclusions, such as an exclusion for share-

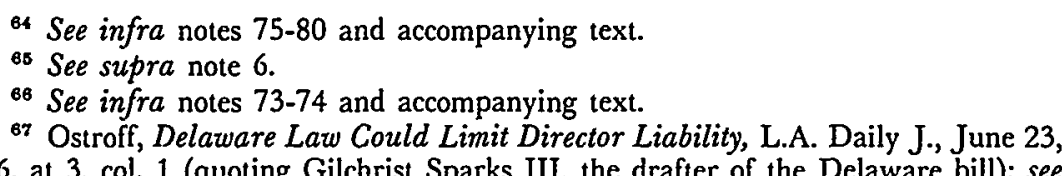
also Synopsis ro DiLAwARE S.B. No. 533, 133D GEN. AsSEMBLy (1986) [hereinafter SYNopsis To DkL. S.B. No. 533] (analyzing legislative response to unavailability of traditional D\&O insurance policies); Black, Jr. \& Sparks III, supra note 63, at 311 (raising concerns about personal liability of directors); Sparks III, supra note 32, at 10, col. 2 (discussing unavailability of insurance); Letter from L. Black, Jr., A. Sparks III, \& J. Johnston of Morris, Nichols, Arsht \& Tunnell, Wilmington, Del., to Glients, at 1 (May 7, 1986) (on file with the University of Pennsylvania Law Review) (same); Proposed Amendments to Sections 102 and 145 of the Delaware General Corporation Law [hereinafter Proposed Amendments] (undated memorandum given to the Delaware Legislature) (on file with the University of Pennsylvania Law Review) (addressing the unavailability of insurance).

68 See supra note 6.

${ }^{69}$ See Hilder, supra note 6, at 21, col. 1. Not coincidentally, Van Gorkom, 488 A.2d 858, was decided on January 29, 1985, opinion dated March 14, 1985, as amended upon denial of rehearing.

${ }^{70}$ Hinsey, supra note 6, 181-85.

71 Id. at $185-86$. 
holder derivative suits, have been included in the policies. ${ }^{72}$ Thus, by any measure, the change in the $\mathrm{D} \& \mathrm{O}$ insurance market has been a violent one.

Still, through all the polemic finger-pointing that has characterized the insurance debate in recent years, the cause of the insurance crisis remains unclear. ${ }^{73}$ Some evidence does exist, however, that a good deal of the insurance industry's woes were self-inflicted through competitive underpricing and questionable management. ${ }^{74}$ The legal system, therefore, is not necessarily the cause of the crisis, and, consequently, legal

72 Id. at 187.

73 For instance, the House of Representatives Subcommittee on Economic Stabilization of the Committee on Banking and Urban Affairs heard testimony that empirical evidence does not support the insurance industry's claim that a major cause of the insurance crisis is an increase in tort litigation. See The Liability Insurance Crisis: Hearings Before the Subcomm. on Economic Stabilization of the House Comm. on Banking, Finance and Urban Affairs, 99th Cong., 2d Sess. 155-66 (1986) (testimony of Ralph Nader, Center for the Study of Responsive Law) (noting that the number of tort claims has risen by $9 \%$, only $1 \%$ more than the increase in population and accounted for in part by double-counting as cases are redocketed and consolidated); $\mathrm{Na}$ der Calls Lawsuit Crisis a Myth, A.B.A. Litigation News, Winter 1987, at 1, 1 (recounting Nader's testimony). But see Lewin, supra note 6, at D1, cols. 3-4 (giving data regarding rising number of cases and costs associated with litigation against directors).

"7t The immediate cause of the sharp premium increases and lack of coverage are losses that insurers suffered from competitive rate cutting of commercial property-liability policies in the six years through 1984 . The companies had hoped to offset claims payments with income earned from investing premium dollars.

But by 1984 , claims and administrative expenses exceeded investment income by $\$ 3.8$ billion. The gap widened to $\$ 5.5$ billion last year, even as premiums jumped $21 \%$ to $\$ 142$ billion, because of unusually heavy hurricane damage. Even so, the industry expects to post net income of $\$ 1.7$ billion because of tax credits and capital gains on stocks sold from investment portfolios.

Insurers acknowledge that many of their financial wounds are selfinflicted .... .

Businesses Struggling to Adapt as Insurance Crisis Spreads, supra note 6, at 31, col. 2:

See also, Hilder, supra note 6 , which provides:

The current market for D\&O coverage, which . . . is "in total disarray," is partly the result of forces that have driven up prices of other kinds of business insurance since late last year. Rates for commercial policies had been falling for six years. Insurers weren't charging enough to cover claims, but they expected to make up the difference by investing premium dollars until claims were paid.

That worked for a while, but rising claims and falling interest rates made the gambit a loser.

Hilder, supra note 6 , at 1 , col. 6 .

It may be noted in this connection that the McCarran-Ferguson Act of 1945 granted federal antitrust immunity to the insurance industry if the state where the insurance company was doing business had regulations in place. See 15 U.S.C. $\S \S 1011-15$ (1982 \& Supp. III 1985). 
reform will not necessarily resolve the insurance industry's problems.

$\mathrm{D} \& \mathrm{O}$ insurance is a relatively new form of insurance, ${ }^{75}$ the propriety of which was questioned early in its existence. ${ }^{76}$ Professor Bishop, responding to arguments that $\mathrm{D} \& \mathrm{O}$ insurance expenditures by corporations constituted justifiable "compensation" of directors, stated:

$[T]$ argue from this premise that the corporation may therefore compensate its directors by purchasing insurance . . . requires the tacit assumption that any kind of "compensation" is necessarily consistent with public policy. ... The argument that the corporation should be able to purchase insurance as "compensation" therefore seems at best sophistical. So long as the law imposes on directors duties of good faith and due care, it should not permit them to evade those duties through the device of insurance purchased by the corporation. ${ }^{.7}$

Despite such criticisms, largely from academic circles, ${ }^{78}$ "virtually all public corporations today carry [D\&O insurance] for their officials."78 The inherent circularity of this firmly entrenched corporate habit has not gone unnoticed. One commentator remarked:

Conceptually, it would be far simpler and more direct if the corporation just insured itself against loss due to the negligent acts or omissions of its agents, rather than using the circular procedure of insuring its agents and then suing them for damages that only the insurance policy it purchased can cover. ${ }^{80}$

Clearly, serious conceptual questions arise as to whether D\&O insurance should exist in the first place.

If the insurance crisis is, in fact, the "driving force" behind the enactment of the Delaware liability-eliminating provision, then that

${ }^{78}$ See Johnston, Corporate Indemnification and Liability Insurance for Directors and Officers, 33 Bus. LAw. 1993, 2012 (1978).

${ }_{36}$ See Bishop, supra note 3, at 1078 n.1, 1086-95; Bishop, New Cure for an Old Ailment: Insurance Against Directors' and Officers' Liability, 22 Bus. LAw. 92, 103114 (1966). But see Johnston, supra note 75, at 2013 ("The public policy arguments against the purchase by the corporation of $\mathrm{D} \& \mathrm{O}$ insurance are now largely moot in view of the statutes in most jurisdictions specifically permitting the purchase of such insurance at the expense of the corporation.").

77 Bishop, supra note 3, at 1091.

78 This criticism, however, does not come exclusively from academic circles. See Farrell, If Directors Are Doing Their Job, They Don't Need Insurance, Bus. WK., Sept. 8, 1986, at 61 .

${ }^{79}$ Coffee, supra note 2, at 805.

so Id. 
seemingly minor provision would appear to be the "tail wagging the dog," and an unpleasant mixed-breed of a dog at that. The Delaware legislature's solution to the $\mathrm{D} \& \mathrm{O}$ insurance problem is an inappropriate response to a powerful stimulus, a stimulus that often prompts impulsive, tort law reform "bandwagon responses." The inappropriateness of Delaware's solution is evident not only as a conceptual matter but also as a practical one. For example, the insurance industry no longer provides coverage for shareholder derivative suits, ${ }^{81}$ presumably having been sensitized to the circularity of a corporation suing its own officials to recover insurance proceeds for which it paid. Yet, in this area in which the purported intent to lower insurance premiums has no relevance, Delaware would still allow the director to escape liability. Thus, citing the harsh conditions of the insurance market as a justification for eliminating duty of care liability is unconvincing. Unfortunately, the directors sitting in boardrooms have not agreed. In fact, many have deserted the boardrooms in response to the unfavorable conditions of the insurance market.

\section{The Exodus of Directors from the Boardrooms}

Fearing the potentially ruinous personal consequences of the recent developments in duty of care jurisprudence and the insurance markets, ${ }^{82}$ many directors across the country have foregone their modest directorship fees $^{\mathbf{8 3}}$ and have abandoned their seats in the boardrooms. Corporations, consequently, have found it increasingly difficult to assemble a competent, independent board of directors. ${ }^{84}$ When scrutinized more closely, however, the recent highly-publicized cases do not constitute adequate justification for mass hysteria. ${ }^{85}$ Furthermore, blaming the unavailability or unaffordability of $\mathrm{D} \& \mathrm{O}$ insurance for mass defection is an argument based on a dubious entitlement. ${ }^{86}$ Hence, the directors may indeed be "crying wolf." Nonetheless, with the approval of the Delaware legislature, ${ }^{87} \mathrm{D} \& \mathrm{O}$ liability insurance almost has become a business necessity. ${ }^{\mathbf{8 8}}$

The Delaware legislature was faced with the real problem of di-

81 See supra text accompanying note 72 .

82 See supra text accompanying notes 30-32 and notes 67-72.

83 See supra note 8.

84 See SYNOPSIS To Del. S.B. No. 533, supra note 67; ALI Draft No. 6, supra note $14, \S 7.17$ comment c; Baum, supra note 4, at 56; Black, Jr. \& Sparks III, supra note 63, at 311; Sparks III, supra note 32, at 10, col. 2 .

${ }^{85}$ See supra text accompanying notes 30-63.

${ }_{88}$ See supra text accompanying notes 75-80.

87 Del. Code ANN. tit. 8, § 145(g) (1983).

${ }^{88}$ See supra note 79 and accompanying text. 
rector resignations or refusals to serve, regardless of how conceptually unsatisfactory the purported causes of the problem appeared. Not surprisingly, Delaware chose to act in a way that would "maintain [its] leadership" tive motivation to stem the tide of board membership depletion is understandable, one must question what effect liability-elimination may have on responsible corporate governance.

The movement in the recent decades toward more independent boards consisting of a healthy mix of outside directors as well as inside directors has affected the corporate world immensely. ${ }^{80}$ Observers have remarked that a "majority of outside directors is now almost a necessity for a public company." Re1 Recently, however, reports indicated that the trend has reversed. ${ }^{92}$ According to one study, the percentage of outside directors on the boards of the largest 1,000 industrial companies has dropped from $63.2 \%$ to $57.5 \%$ in 1986 , the first decline since 1966 when the studies began. ${ }^{93}$

These developments appear ominous, especially when cast against the background of judicial enthusiasm for independent outside directors. Courts, in fact, sometimes have extended a near presumption of legitimacy to board decisions in which a good number of outside directors have participated. ${ }^{94}$ Thus, in Moran $v$. Household International, Inc., ${ }^{95}$ the Delaware Supreme Court stated that in applying the business judgment rule to antitakeover defensive mechanisms, the directors' proof is "materially enhanced ... where . . . a majority of the board favoring the proposal consisted of outside independent directors

${ }^{80}$ Proposed Amendments, supra note 67, at 1. See generally Note, Delaware's Limit on Director Liability: How the Market for Incorporation Shapes Corporate Law, 10 Harv. J.L. \& PuB. Pol'y 665, 687-88 (1987) (discussing Delaware's quick response to the directorship crisis in order to maintain its leading role in the incorporation of businesses).

${ }^{80}$ See Baum, supra note 4, at 56; Sparks III, supra note 32, at 10, col. 1. For recent debates regarding the role of independent boards, see Baysinger \& Butler, Revolution Versus Evolution in Corporation Law: The ALI's Project and the Independent Director, 52 Geo. Wash. L. Rev. 557 (1984); Karmel, The Independent Corporate Board: A Means to What End?, 52 Geo. Wash. L. Rev. 534 (1984); Kennedy, supra note 2 , at 633.

91 Henderson, Olson \& Hatch, supra note 49, at 275; see also R. CLARK, supra note 18, § 3.2.1; Baum, supra note 4, at 56 (discussing how "[c]ompanies are being forced to employ professional recruiters to search for top flight executives" to become board members).

${ }^{92}$ See Baum, supra note 4, at 56.

83 Id. at 57.

84 Of course, no level of outside director involvement can offer blanket immunity. See, e.g., Hanson Trust, 781 F.2d at 267-69 (nine out of twelve directors were outsiders and unanimously approved the defensive measure); Van Gorkom, 488 A.2d at 868 (five out of ten directors were outsiders).

gs 500 A.2d 1346 (Del. 1985). 
. . ."98 Similarly, the Seventh Circuit, in Panter v. Marshall Field E Co., ${ }^{97}$ stated that "[t]he presumption of good faith which the business judgment rule affords is heightened when the majority of the board consists of independent outside directors."98

Intuitively, the appeal of having a board partially composed of outside directors is founded upon the assumption that independent persons, whose welfare is not closely tied to the corporation, help create a more conscientious board, one that is less susceptible to the temptations of self-entrenchment and self-enrichment. The validity of this assumption, however, and the appropriate role of the independent director in general are the subject of debate. ${ }^{98}$

Presently, the most widely-recognized view of the board function is the monitoring model. ${ }^{100}$ Within that model, a higher standard of diligence in corporate management is applicable to inside directors because of the "intimate knowledge of corporate affairs"101 that their positions afford them. Outsiders, on the other hand, "should not attempt to run the corporation or arbitrarily to substitute their judgment for that [of] management. . . . [A]ll that the monitoring function implies is a willingness to be vigilant and questioning in the effort to determine what is in the best interest of the corporation." "102

Conversely, while outsiders may have a lesser duty to manage, they may have a heightened duty, in some circumstances, to monitor those who in fact manage. In Hanson Trust, the Second Circuit stated that "[i]n the context of a self-interested management proposing a defensive [leveraged buyout], the independent directors have an important

${ }^{96} \mathrm{Id}$. at 1356 .

97 646 F.2d 271 (7th Cir.), cert. denied, 454 U.S. 1092 (1981).

88 Id. at 294.

89 See Baysinger \& Butler, supra note 90, at 558.

100 This view is reflected in the modern statutory model of corporate governance that the business affairs of the corporation shall be managed "under the direction of" the board of directors, as opposed to managed "by" the board. See MoDEL AcT, supra note $1, \S 8.01$ (b). For a discussion of this trend toward a monitoring board, see W. CARY \& M. EISENBERG, supra note 19, at 140 (stating that recent state statutes have adopted the language "managed under the direction of" a board of directors, thus eschewing the requirement of "active involvement by the board in day-to-day affairs of the corporation"); Committee on Corporate Laws, Section of Corporation, Banking and Business Law, American Bar Association, Corporate Director's Guidebook, 33 Bus. LAw. 1591, 1606-07 (1978) ("' $[\mathrm{t}]$ he phrase 'managed under the direction of" was inserted . . . to replace the phrase "managed by" "); $c f$. DeL. Code ANN. tit. 8, § 141(a) (1983) (stating "[t]he business and affairs of every corporation organized under this chapter shall be managed by or under the direction of a board of directors").

${ }^{101}$ Feit v. Leasco Data Processing Equip. Corp., 332 F. Supp. 544, 578 (E.D.N.Y. 1971).

${ }^{102}$ Rowen v. Le Mars Mut. Ins. Co., 282 N.W.2d 639, 652 (Iowa 1979) (quoting Leech, The Outside Director of the Publicly Held Corporation, 31 Bus. LAw. 1799, 1805 (1976)). 
duty to protect shareholder interests, as it would be unreasonable to expect management . . . fully to represent the shareholders." ${ }^{103}$ Thus, there already is in place a very loose system of directorial governance, one that takes into account the time and information constraints of modern business and that allows wide variability in the level of involvement of the independent directors. ${ }^{104}$ It is against this backdrop that the Delaware legislature sought to alleviate the problem of "directors' concerns about personal liability [that] were causing Delaware corporations to lose, or to be unable to attract, qualified men and women to serve on their boards." 105

Nevertheless, when adopting legislation that alters the dynamics of corporate governance, merely reciting the monitoring ideal of board composition and then uncritically adopting measures intended to ensure full board membership is troubling, at best. First, it is unclear that implantation of outside directors reliably generates ideally independent corporate boards. After all, structural biases operating to suppress nonconforming points of view can permeate the director selection process. Professor Clark has opined that:

It is a notorious fact that in the overwhelming majority of elections for directorships in public corporations the public shareholders simply vote for whomever is proposed by the corporation's official nominating committee. . . [T] [Tis committee of the board was often made up of directors who were officers, or friends of the officers, and it was careful to nominate only candidates who were likely to be well disposed to incumbent management. Nominees tended to be agreeable, chummy persons, usually of the same social class as the incumbents. . . . Today, it may be the case that the characterization is becoming less valid more generally, because more nominating committees contain a majority of outside directors. But since most outside directors on these committees were originally identified by officers, and since there is a kind of social compact among most businessmen at the topofficer and director level, substantial change in the intensity and seriousness with which boards act as monitors may be

103 Hanson Trust, 781 F.2d at 277.

104 One commentator has summed it up this way: "[W]ith respect to many business decisions, outside directors should be thought of not as major contributors to the substantive content of decisions or as shapers of specifics, but rather as critical reviewers with a power of rejection." Kennedy, supra note 2, at 635.

${ }^{105}$ Black, Jr. \& Sparks III, supra note 63, at 311. 
slow in coming. ${ }^{108}$

Second, the ideal of board independence may contribute to a reduction in the quality of the outside director's input. Not only has the monitoring model required only a minimal level of involvement from outside directors, ${ }^{107}$ but it also has given incentive for some "professional directors" to serve on many boards, ${ }^{108}$ thereby further lowering acceptable limits of outsider involvement. In an extreme case, a retired Citibank executive lent his services to eighteen different boards, eleven of them public. ${ }^{109}$ Consequently, it is not surprising that "many corporate governance gurus [have questioned] whether professional directors are stretched too thin to fulfill their board obligations."110 Such developments have highlighted the fact that the movement toward the independent board has had the unfortunate side effect of placing a higher premium on quantity of outside directors than on quality of those directors' participation. ${ }^{111}$

The Delaware-type liability-limiting provisions appear to exacerbate this trend. Although corporations having seriously depleted boards may find their situation intolerable, eliminating directors' liability for violations of the duty of care constitutes a questionable remedy-one that fails to take into account all deleterious side effects. ${ }^{112}$

Delaware's approach to the depletion problem is undesirable because it ironically eviscerates the very mechanism for ensuring the quality of director services. Under the provision, directors no longer need worry about whether they are serving on too many boards and devoting too little time to each; they no longer need face consequences of negligently missing crucial meetings; they no longer need fret about informing themselves adequately before approving the sale of the company. Indeed, although Delaware's "open-door" policy may lead to

${ }^{108}$ R. Glark, supra note $18, \S 3.2 .1$; see also Baum, supra note 4 , at 56 ("[T]oday there are a lot of so-called outside directors who are not all that independent: They are close friends of the chief executive, or perhaps of the company's banker, lawyer, or management consultant."); The Business Roundtable, The Role and Composition of the Board of Directors of the Large Publicly Owned Corporation, 33 Bus. LAw. 2083, 2092-94 (1978) (surveying various criticisms of boards today and suggesting proposals for reform).

107 See supra notes $100-06$ and accompanying text.

${ }^{108}$ See Baum, supra note 8, at 59.

${ }_{108} I d$.

${ }_{110} I d$.

111 Some have cited this unfortunate trend toward the ineffective participation of directors in too many boards as presenting one reason that the D\&O insurance crisis may prove beneficial. They argue that the tighter insurance market could improve the quality of corporate boards by forcing directors to serve on a smaller number of boards and, thus, to participate more attentively. See Hilder, supra note 6 , at 1, col. 6 .

${ }^{112}$ Possible alternative approaches will be discussed in Section III. 
boards that are constituted more fully, the seats may be occupied by "rubber-stamp" members who add little or nothing to the management of the corporation. Many argue, however, that natural market forces will deter directorial misbehavior and that the duty of care, therefore, is superfluous. ${ }^{113}$ Part II will address this argument through a discussion of the debate surrounding the compensatory and deterrent functions of the duty of care.

\section{Rationales Underlying the Duty of Care}

\section{A. The Compensation Function}

It sometimes is stated that a breach of the director's duty of care gives rise to a cause of action in tort. ${ }^{114}$ Torts have been defined as "a body of law which is directed toward the compensation of individuals, rather than the public. . . . The law of torts . . . is concerned with the allocation of losses arising out of human activities . ..."115 Hence, at first glance, compensating injured shareholders appears to be a central function of the duty of care. Some commentators, however, have argued that traditional tort concepts do not lend themselves well to the corporate context. ${ }^{116}$ Indeed, the ALI Corporate Governance Project, for example, has abandoned the compensation rationale. ${ }^{117}$ The ALI cites three main reasons for doing so: 1) the difficulty of victim identification and damage estimation; 2 ) the unfairness of imposing potentially tremendous financial burdens on "part-time participant[s] in the corporation's affairs"; and 3) the chilling effect on the incentive to serve as directors. ${ }^{118}$

Yet there is no reason why a court should not award damages in a

113 See, e.g., R. Posner, Economic Analysis of Law 383 (3d ed. 1986) (arguing that managers have strong incentive to manage firms well, because mismanagement eventually leads to bankruptcy of the firm and to destruction of the managers' future employment prospects, as a result of the competition of better managed rival firms); Fischel \& Bradley, supra note 2, at 262-63 (suggesting that mechanisms other than liability rules create incentives for managers to fulfill obligations); Scott, supra note 28 , at 935-37 (stating that apart from shareholder legal actions, other pressures and incentives bear on management's performance, such as competition in product and capital markets, the managerial labor market, and executive incentive-compensation arrangements).

${ }_{114}$ See, e.g., Barnes v. Andrews, 298 F. 614, 616 (S.D.N.Y. 1924) (allegation that director failed to devote adequate attention to company's affairs states a cause of action in tort).

116 W. Kefroton, D. Dobbs, R. Keeton \& D. Owen, Prosser \& Keeton on THE LAW OF ToR'rs $\S 1$ (5th ed. 1984) [hereinafter PROSSER \& KEETON].

116 See, e.g., Kennedy, supra note 2, at 630.

117 ALI DRAFr No. 6, supra note $14, \S 7.17$ comment c.

118 Id. 
breach of duty action in which these three considerations are not insurmountable. Imagine, for example, a situation in which the inside management of a closely held corporation perpetrated a massive, well-concealed fraud that forced the company into an unexpected bankruptcy and scandal. That corporation's small number of shareholders awoke one morning to find that their stocks were worthless. In the litigation that ensued, evidence showed that the independent directors had been grossly inattentive and, on the rare occasions when they did attend to company matters, had acted as mere rubber stamps.

In this hypothetical, knotty problems of identifying and evaluating losses are not insignificant. In addition, any chilling effect on the incentive to serve as a director would be minimal, given the exaggerated nature of the directors' breach of duty. At any rate, potential chilling effects on those who fear liability for violations as outlandish as these would represent positive, not negative, consequences of a damage award. No one wants individuals capable of such neglect serving as directors in the boardroom. Furthermore, the fact that the directors in this hypothetical served only as part-time members should not excuse their misconduct or limit their liability, particularly because their liability is based upon the very fact that their participation was substantially part-time. The preceding hypothetical is intended to illustrate the point that since duty of care jurisprudence always has proceeded, and should continue to proceed, on a case-by-case basis, ${ }^{119}$ in the rare instances in which the problems associated with the compensation rationale are not burdensome, the concern for compensating injured shareholders should not be compromised.

In light of the preceding discussion, one certainly may ask why the compensation rationale should be treated as a "second-class" rationale in the first place. Professor Cox has argued that "there is no genuine conflict between either compensation or deterrence in a good many cases . . . ."120 Professor Coffee, on the other hand, argues along much the same line, as the ALI, stressing the circularity of modern mecha-

119 See, e.g., Harman v. Willbern, 374 F. Supp. 1149, 1161 (D. Kan. 1974), aff d, 520 F.2d 1333 (10th Cir. 1975) (each case determined in view of its peculiar circumstances); Graham v. Allis-Chalmers Mfg. Co., 41 Del. Ch. 78, 87, 188 A.2d 125, 130 (1963) (liability depends on circumstances and facts of particular case); Kutik v. Taylor, 80 Misc. $2 d$ 839, 841, 364 N.Y.S.2d 387, 390 (Sup. Ct. 1975) (duty of care measured by the circumstances); Selheimer v. Manganese Corp. of Am., 423 Pa. 563, 581, 224 A.2d 634, 644 (1966) (negligence is a question of fact determined under all circumstances). The case-by-case approach is also consistent with the trend toward a more subjective standard of conduct required of directors, as seen in the common statutory language calling for the care of "an ordinarily prudent person in a like position ... under similar circumstances." See supra notes 19-21 and accompanying text.

${ }^{120}$ Cox, supra note 27 , at 776 . 
nisms for recovery under the compensatory rationale, in which the corporation recovers from itself for the mismanagement by one of its agents. ${ }^{121}$

Despite its uncomfortable "fit" with the realities of modern corporate structure, the compensation rationale should not be abandoned. Just as the duty of care should continue to exist in an unobtrusive but useful capacity, ${ }^{122}$ the compensation rationale likewise should persist. Professor Coffee concludes his analysis of the relationship between the compensatory and deterrent rationales with a compromise position: that of treating the compensatory rationale as a limitation on the deterrent rationale. ${ }^{123}$ According to Professor Coffee, the deterrent rationale, when taken to its logical extreme, can justify infinite litigation expenditures for gains in deterrence that are not commensurate with the costs. The compensation rationale, however, can temper such costs because, under that theory, expenditures exceeding the sum lost could not be justified as they would not produce a net recovery. ${ }^{124}$

But what of the instances when the deterrent rationale would lead to a recovery less than that indicated by the compensation rationale because, for instance, a court is overly worried about the chilling effects deterrence would have on directors' willingness to serve? This Gomment agrees with the basic case-by-case balancing scheme adopted by Professor Coffee. ${ }^{125}$ However, the compensation rationale should operate independently to permit a higher recovery than the deterrent rationale in the rare cases of extreme negligence in which the problems of identifying victims and estimating damages are not insurmountable. Having discussed the compensation rationale, the next section will turn to its corollary, the deterrence rationale.

\section{B. The Deterrence Function}

Commentators have attacked the duty of care as a superfluous rule of law that does nothing to improve corporate governance ${ }^{126}$ but instead

121 Coffee, supra note 2, at 805 (The problem is that "the source of any recovery is ultimately the officers' and directors' liability insurance policy . . . . Because the premiums on these policies are typically paid by the corporations, these corporations are simply funding their own recovery.").

${ }_{122} C f$. id. at 796 . Professor Coffee states that "[r]ather than being a nullity insofar as its affect on financial liability is concerned, the duty of care has led a twilight existence, marginally affecting the size of settlements . . ." However, he also recognizes the educational and socializing effects of the duty of care.

${ }^{123} I d$. at 807.

124 Id. at 807-808.

325 Id. at 808. 935-37.

${ }^{128}$ See, e.g., Fischel \& Bradley, supra note 2, at 262-63; Scott, supra note 28, at 
actually impedes it by striking terror into the hearts of competent persons who otherwise are willing to provide their services as board members. Moreover, others argue that the duty inhibits directors' entrepreneurial instincts, deterring them from taking justifiable business risks. ${ }^{127}$ But the duty of care has always served, and will continue to serve, an important deterrent function-broadly as an "aspirational statement"128 and narrowly as a remedial tool when other marketbased deterrents have failed. Any statutory modification of the directors' duty of care must take these essential factors into account. This Section will analyze, first, the market deterrents against directorial misbehavior; second, the aspirational role of the duty of care; and, finally, the residual deterrent function of the duty of care.

As a preliminary matter, however, one should note that analysis of the deterrent effects of the duty of care is clouded considerably by the fact that disputes often are resolved by settlement. Professor Coffee remarked, with regard to a thesis of Professor Bishop: $:^{129}$

Professor Bishop's thesis . . . ignores the central facts that cases are most often resolved by settlement, not judicial decision, and that defendants have a particularly strong incentive to settle derivative actions because, unlike settlement, an adjudication adverse to them will typically deprive them of eligibility for indemnification. As a result, it is likely that cases favorable to the plaintiff tend to be settled, whereas those in which the defendant has the relative advantage tend to be dismissed at a pretrial stage, often in recorded decisions. In this settlement process, the parties necessarily bargain in the shadow of the law .... ${ }^{330}$

Interestingly, this observation supports either of two opposite conclusions: that the duty of care should be preserved in light of its historical role as a deterrent ${ }^{131}$ or that the duty should be limited in light of its incentive for nuisance, or "strike," suits. ${ }^{132}$ These conclusions, ostensi-

${ }^{127}$ See ALI DRAFT No. 6, supra note 14, $\$ 7.17$ reporter's note 2; Fischel \& Bradley, supra note 2, at 270; Scott, supra note 28, at 936.

${ }^{128}$ W. KLein \& J. Coffee, JR., supra note 3, at 141.

128 Professor Bishop advanced the position that the number of cases holding directors liable for pure negligence, uncomplicated by self-dealing or bad faith, is extremely small. See supra notes 3,15 and accompanying text.

${ }^{130}$ Coffee, supra note 2, at 796 (footnote omitted); see also R. CLARK, supra note $18, \S 3.4 .1$, at 126 (noting that plaintiffs with strong cases nevertheless tend to settle).

${ }^{131}$ See, e.g., Coffee, supra note 2, at 797 ("[I]t is myopic to evaluate the law's impact without taking into account the nonadversarial processes by which lawyers advise clients and thereby shape the behavior and consciousness of their clients.").

132 See, e.g., ALI DRAFT No. 6, supra note $14, \S 7.17$ comment c (noting that 
bly at odds with one another, can be harmonized. The fear of strike suits should not precipitate the automatic abolition of due care liability, nor should the need for deterrence subject courts to a flood of frivolous litigation. A reasonable compromise can be found to meet the exigencies of the 1980's.

Some of the arguments in favor of abolishing the duty of care have come from the law and economics school of thought. ${ }^{133}$ Judge Posner wrote:

The danger of mismanagement (negligence) is less serious than the danger that the managers will not deal fairly with the shareholders (disloyalty). Mismanagement . . . will lead eventually to the bankruptcy of the firm . . . as a result of the competition of better managed rivals. . . . The managers thus have a strong incentive to manage the firm well or, if they are unable to manage it well themselves, to sell their offices to those who can. . . .134

Professor Scott, also arguing from an economic perspective, lists several natural market forces that influence management's performance: competition in the product, capital, and managerial labor markets; the desire of directors to fulfill executive incentive compensation arrangements; and the need of directors to protect their own reputations. ${ }^{135}$

A related line of reasoning, the "entrepreneurial argument," has had a powerful impact on duty of care jurisprudence and scholarship. ${ }^{136}$ Stated simply, this argument posits that "the duty of care may deter directors and their corporations from taking business risks, thereby chilling innovation and creative activities, which the law ought to encourage."137 This view recognizes the fact that "the number of

the proposed limitation on due care liability reduces the incentive to sue). "Strike" suits are claims brought for their nuisance or settlement value, not necessarily for, and sometimes despite the total lack of, merit.

${ }^{133}$ See, e.g., Scott, supra note 28, at 947 ("Nor am I encouraged by the total absence of reference to and discussion of the considerable economic literature of the theory and functioning of the firm.").

134 $R$. POSNER, supra note 113 , at 383.

1ss See Scott, supra note 28, at 935-36; see also Fischel \& Bradley, supra note 2, at 274-76 (discussing effective governance mechanisms).

136 The profound undercurrent of what this Comment labels the "entrepreneurial argument" can be observed in the attenuated judicial distaste for meddling with business judgments with the benefit of perfect hindsight, a sentiment that is formalized by the business judgment rule. See supra notes $22-28$ and accompanying text; see also cases cited in ALI DRAFT No. 6, supra note 14, $\S 7.17$ reporter's note 2 (indicating that concern over liability may make corporate directors unduly risk-averse or discourage them from serving on boards at all).

${ }^{137}$ Frankel, Corporate Directors' Duty of Care: The American Law Institute's Project on Corporate Governance, 52 Geo. Wash. L. Rev. 705, 713 (1984); see also 
matters [a board of directors] might conceivably address is indefinitely large . . . [and that] there has to be some margin for error in those judgments." 138 The entrepreneurial argument is particularly persuasive because it shares many of the basic premises of the capitalist system. Nevertheless, this argument does not adequately justify the abandonment of the duty of care. As discussed in Sections IA and B above, courts traditionally have respected the entrepreneurial rationale, and the recent, highly-publicized cases do not indicate that this deep-rooted sentiment has vanished.

Even if one accepts the premises of both the entrepreneurial and economic market-based arguments, it does not follow that the duty of care should be abolished. Professor Coffee has responded to the marketbased arguments by asserting that the duty of care, as a normative standard, is beneficial because of its "educational and socializing effect."139 He states that the "reductionist approach ignores the important educational and aspirational role that the law ... [has] long played in our society in setting standards."140

But this "social utility" argument in favor of keeping the duty of care, by itself, is not totally convincing. It is not clear why this educational mission should be borne by the legal system, with its high transaction costs associated with litigation, especially in an area in which law traditionally has shown great deference to the judgments of professionals in another field. Professor Coffee summarily states that if the task of setting normative standards were left to business groups, the result would be "an exercise in self-insurance . . . to eliminate any possibility of liability or litigation."141 However, evidence to the contrary suggests that market forces generally do a good job of stifling such inefficient, self-serving behavior. ${ }^{142}$

Nevertheless, while the aspirational function is not, by itself, sufficient justification for the existence of the duty of care, the importance of the socializing effect of law should not be overlooked. Some argue that

ALI Drafr No. 6, supra note $14, \S 7.17$ reporter's note 2 (sympathizing with arguments against chilling effects on innovation); Fischel \& Bradley, supra note 2, at 270 (same); Scott, supra note 28, at 946 (same).

138 Kennedy, supra note 2, at 633.

139 Coffee, supra note 2, at 796; see also W. KLEIN \& J. CoffeE, JR., supra note 3 , at 141 (noting precatory and hortatory values).

140 Coffee, supra note 2, at 792-93. As a liability-setting standard, however, the duty of care is not viewed by Professor Coffee as sound social policy because directors are poor cost avoiders (except in the context of monitoring law compliance) and because managers and directors are more risk-averse than shareholders desire. Id. at 801-802.

${ }_{141}$ Id. at 798 (footnote omitted). This is an interesting comment in light of recent enactments by various states of liability-limiting provisions.

142 See Fischel \& Bradley, supra note 2, at 263-74. 
the laws of our society have always served this vital educational role. ${ }^{143}$ From this perspective, then, the aspirational characteristics of the duty of care act like a "velvet glove," deterring potentially negligent actors who are amenable to such gentle prodding.

The weakness of both the market-based system and the aspirational scheme is that there are corporate managers who refuse to conform their behavior in response to either economic or social pressures. The duty of care also can represent the "fist in the velvet glove" to those unresponsive to ephemeral market forces or aspirational maxims. The duty of care, then, should serve as 1) a minimal standard of care, one that is even more tolerant than general market demands, and 2) a remedial tool that courts may invoke in especially egregious, marketfringe situations. An overview of duty of care jurisprudence suggests that it traditionally has served these limited, but valuable, purposes. ${ }^{144}$ The duty of care as it is generally understood today requires only the bare minimum of directorial diligence. ${ }^{145}$ This fact should not be lost amidst cries of draconian personal liability.

What the duty of care amounts to today is an obligation to "show up"146 and inform oneself, ${ }^{147}$ and not much else. Surely, these standards are less exacting than the demands of the market, which places a premium on competence and expertise. Yet, a sizable number of cases do exist in which market forces failed to influence the behavior of corporate directors. ${ }^{148}$ These cases highlight the existence of directors who

${ }^{143}$ See Coffee, supra note 2, at 798 ("At least within our society . . . the legal profession has generally enjoyed a hegemony over this educational function of communicating standards to the relevant audience.").

144 See supra text accompanying notes 15-29.

$145 I d$.

${ }^{146}$ See supra text accompanying notes 33-39 (discussing inactive or figurehead directors).

${ }^{147}$ See supra text accompanying notes $40-54$ (discussing Smith v. Van Gorkom, 488 A.2d 858 (Del. 1985)).

${ }_{168}$ The following are cases involving some form of neglect of duty by a director, including abdication of duty, figurehead directors, inactive directors, and out-of-state directors: Bowerman v. Hamner, 250 U.S. 504 (1918) (abdication); In re Happy Time Fashions, Inc., 7 Bankr. 665 (Bankr. S.D.N.Y. 1980) (neglect of duty); Heit v. Bixby, 276 F. Supp. 217 (E.D. Mo. 1967) ("lackadaisical" discharge of duty); King v. Livingston Mfg. Co., 192 Ala. 269, 68 So. 897 (1915) (neglect); Minton v. Cavaney, 56 Cal. 2d 576, 364 P.2d 473, 15 Cal. Rptr. 641 (1961) (neglect); Rowen v. Le Mars Mut. Ins. Co., 282 N.W.2d 639 (Iowa 1979) (neglect); Dinsmore v. Jacobson, 242 Mich. 192, 218 N.W. 700 (1927) (nonresident director); Doyle v. Union Ins. Co., 202 Neb. 599, 277 N.W.2d 36 (1979) (rubber-stamping directors); Francis v. United Jersey Bank, 87 N.J. 15, 432 A.2d 814 (1981) (inactive director); Brinkerhoff v. Bostwick, 88 N.Y. 52 (1882) (inattentive director); Platt Corp. v. Platt, 42 Misc. 2d 640, 249 N.Y.S.2d 1 (Sup. Ct. 1964) (neglect); Van Schaick v. Aron, 170 Misc. 520, 10 N.Y.S.2d 550 (Sup. Ct. 1938) (inattention); Mobridge Community Indus. v. Toure, Ltd., 273 N.W.2d 128 (S.D. 1978) (neglect); Neese v. Brown, 218 Tenn. 686, 405 
are either oblivious to or unaffected by market or social pressures. Could any amount of market pressure or any particular aspirational maxim possibly have made Mrs. Pritchard ${ }^{149}$ either perform her duties or find a replacement? Similarly, why did market forces relied upon by economic analysis commentators ${ }^{\mathbf{1 5 0}}$ fail to deter Jerome Van Gorkom's actions? ${ }^{151}$

Descriptions of these fringe groups are as varied as the particular facts of the particular cases. Some groups of directors are not "repeat players" and, therefore, have little to risk in terms of reputation or other marketable assets. ${ }^{162}$ Others are "one-time players."163 Consequently, the legal deterrence embodied within the duty of care continues to be essential in those situations in which market deterrents have failed. To abandon the duty of care solely because market forces are adequate to control most cases of directorial misbehavior would constitute an action as hasty and unwise as the decisions made by Jerome Van Gorkom.

Thus, the analytic templates against which Delaware's liabilitylimiting provision, as well as other approaches to the directorship crisis, ${ }^{154}$ will be measured have been set. To summarize thus far: 1) the duty of care has led a "twilight existence," deferring in most situations to business judgment; ${ }^{168}$ 2) recent highly-publicized cases do not signal dramatic changes in duty of care jurisprudence; ${ }^{1.58} 3$ ) the insurance crisis is a complex problem that should not be addressed by an inappropriate legislative response; ${ }^{157} 4$ ) the flight of directors is a serious problem that demands that legislatures respond with solutions placing proper emphasis on the quality of director participation, and not just on the quantity of directors; ${ }^{158} 5$ ) the compensation rationale should be preserved as a basis for recovery in the limited number of cases in which the problems traditionally associated with compensating victims

S.W.2d 577 (1964) (inactive director).

149 She was the director involved in Francis, 87 N.J. 15, 432 A.2d 814. See supra text accompanying notes 33-39.

180 See supra notes $133-35$ and accompanying text.

$161 \mathrm{He}$ was the central figure in Van Gorkom, discussed supra text accompanying notes $40-54$.

${ }^{162}$ Jerome Van Gorkom, who was planning to retire, arguably could be included in this category.

163 Fischel and Bradley concede that liability rules would be useful for such "oneshot fraud" situations. See Fischel \& Bradley, supra note 2, at 270.

${ }_{154}$ See supra text accompanying notes 10-14.

183 See supra text accompanying notes 19-28.

160 See supra text accompanying notes 30-62.

${ }_{152}$ See supra text accompanying notes 64-81.

158 See supra text accompanying notes 107-13. 
are not present; ${ }^{169}$ and 6) the duty of care serves as a basic deterrent that should not be discarded merely because one is dazzled by the overall efficiency of market forces. ${ }^{180}$

\section{The Legislative Proposals}

\section{A. Indiana and Virginia: Lowering the Standard of Care for Directors}

Indiana and Virginia have drastically reduced the standard of care required of directors. ${ }^{161}$ For example, a director in Indiana is no longer liable for her breach of the duty of care ${ }^{\mathbf{1 6 2}}$ unless that "breach or failure to perform constitutes willful misconduct or recklessness."163 Virginia has progressed further in this "race for the bottom,"164 requiring only that directors exercise "good faith business judgment of the best interests of the corporation."16s Unfortunately, both approaches are seriously flawed: Indiana's, because the vagueness of the law renders it incapable of ameliorating the insurance and exodus problems; ${ }^{166}$ Virginia's, because the overbreadth of the law effectively abolishes the duty of care and unwisely sacrifices the fundamental deterrent values embodied in that duty. ${ }^{167}$

The Indiana duty of care statute is virtually identical to the corresponding provision of the Model $\mathrm{Act}^{\mathbf{1 6 8}}$ except for its liability provision. The Model Act, as yet unresponsive to the recent insurance and liability problems, ${ }^{169}$ only shields directors from liability "if" they have complied with the related duty of care subsections. ${ }^{170}$ Indiana, on the other hand, shields directors from liability "unless" the director breached the duty of care, and the breach is so blatant as to constitute willful mis-

159 See supra text following note 125 .

180 See supra text accompanying note 128 and notes $146-53$.

161 See supra note 13.

182 See IND. CODE ANN. $\S 23-1-35-1$ (a) (West Supp. 1987) (requiring that the director of a corporation discharge her duties in good faith, with prudence, and "in a manner [she] reasonably believes to be in the best interests of the corporation").

${ }_{163} I d$. at $\$ 23-1-35-1$ (e) (emphasis added).

164 This well-known phrase was used to describe the trend toward "liberalizing" state corporations"codes. "Liberal" corporations codes characteristically impose only the bare minimum of legal restrictions and requirements, sometimes "water[ing] the rights of shareholders vis-à-vis management down to a thin gruel" in the process. W. CARY \& M. EISENBERG, supra note 19 , at 9 .

165 VA. CODE ANN. § 13.1-690(A) (1985) (emphasis added).

${ }^{168}$ See supra notes $64-113$ and accompanying text.

167 See supra notes $146-53$ and accompanying text.

168 See supra note 1.

168 The latest Model Code was promulgated in the spring of 1984.

170 MODEL Acr, supra note $1, \S 8.30$ (d). 
conduct or recklessness. ${ }^{171}$ Thus, the burden of proof with respect to liability has shifted from the defendant director to show compliance with the duty of care to the plaintiff to show noncompliance, plus willfulness or recklessness on the part of the director. ${ }^{172}$

The question still remains, however, whether directors of Indiana corporations really have reason to look forward to lower insurance premiums and fully-staffed boards. The answer is negative, because as Trans Union ${ }^{\mathbf{1 7 3}}$ shows, legislative exercises in semantics with respect to levels of care are essentially meaningless and only provide courts with room to apportion blame as they see fit. Prosser and Keeton explain the nature of gross negligence (the standard utilized by the Trans Union court), recklessness, and similar standards:

The prevailing [view] is that there are no "degrees" of care or negligence, as a matter of law; there are only different amounts of care, as a matter of fact. From this perspective, "gross" negligence is merely the same thing as ordinary negligence, "with the addition . . . of a vituperative epithet."

$\cdots$

.. . [Willfulness, wantonness or recklessness] looks to the actor's real or supposed state of mind . . . what has been called "quasi-intent."

... Since, however, it is almost never admitted, and can be proved only by the conduct and the circumstances, an objective standard must of necessity in practice be applied. The "willful" requirement, therefore, breaks down and receives at best lip service, where it is clear from the facts that the defendant, whatever his state of mind, has proceeded in disregard of a high and excessive degree of danger, either known to him or apparent to a reasonable person in his position.

... As a result there is often no clear distinction at all between such conduct and "gross" negligence, and the two have tended to merge and take on the same meaning 174

Hence, had Trans Union occurred in Indiana, it might have been de-

171 IND. Code ANN. § 23-1-35-1(e) (West Supp. 1987).

172 Virginia explicitly fixes the distribution of the burden of proof. See VA. CoDE ANN. §13.1-690(D) (1985) ("A person alleging a violation of this section has the burden of proving the violation.").

${ }^{173}$ Smith v. Van Gorkom, 488 A.2d 858 (Del. 1985), discussed supra notes 40-54 and accompanying text.

174 Prosser \& Keeton, supra note $115, \S 34$, at 210-14 (footnotes omitted). 
cided in the same manner, and the problems about which directors complain today might not have been avoided. The uncertainty of outcome under a malleable standard such as "recklessness" renders the legislative attempt to reduce the incentive to sue wishful guesswork, at best.

Virginia's standard of care, ${ }^{175}$ on the other hand, does not suffer from the kind of uncertainty that marks the Indiana provision. By requiring only good faith ${ }^{178}$ business judgment, Virginia's duty is in substantial accordance with Professor Scott's recommendation ${ }^{177}$ that the duty of care be buried, leaving shareholders with only the duty of loyalty to keep a check on those who manage shareholders' investments. Presumably, even in Virginia, inactivity or abdication of duty by a director will still give rise to liability, because directors must exercise some "business judgment"178 before they seek the shelter of the liability shield. ${ }^{179}$ Nevertheless, by abrogating the negligence-based standard of care, Virginia has denied to its corporate shareholders the deterrent value of the duty of care. ${ }^{180}$

The approaches adopted by Indiana and Virginia to lower the standard of care required of directors fail to maintain the delicate balance between corporate stability and shareholders' rights. Their approaches will have uncertain or unhealthy ramifications on corporate governance and may adversely affect shareholders' rights. In contrast, Delaware-type liability-adjusting provisions represent a more sophisti-

176 See supra note 13.

176 A breach of "good faith" traditionally entails some intent to defraud or deceive. See, e.g., Davis v. Louisville Gas \& Elec. Co., 16 Del. Ch. 157, 169, 142 A. 654, 659 (1928) ("The director['s] . . . judgment unless shown to be tainted with fraud is accepted as final. The judgment of the directors of corporations enjoys the benefit of a presumption that it was formed in good faith. . . .").

${ }^{177}$ See Scott, supra note 28.

178 VA. CODE ANN. \& 13.1-690(A) (1985). The director could conceivably argue that it was her "good faith business judgment of the best interests of the corporation" that she lend her reputation to the corporation by accepting a directorship position without actively participating because of, for example, constraints of time or distance. But see Bowerman v. Hamner, 250 U.S. 504, 513-14 (1919):

[The defendant director] was a man of such importance and reputation that the use of his name must have contributed to securing the confidence of the community and of depositors for the bank, and it would be a reproach to the law to permit his residence at a distance from the location of the bank, a condition which existed from the time he first assumed the office of director, to serve as an excuse for his utter abdication of his common-law responsibility for the conduct of its affairs and for the flagrant violation of his oath of office when it resulted in loss to others.

179 See VA. CoDE ANN. $§ 13.1-690(C)$ (1985) ("A director is not liable for any action taken as a director, or any failure to take any action, if he performed the duties of his office in compliance with this section.").

${ }_{180}$ See supra notes $146-53$ and accompanying text. 
cated approach. The Delaware provision, however, engenders many of the same problems faced by the Indiana and Virginia statutes.

\section{B. Delaware's Approach: Enabling the Corporation to Limit or Eliminate Liability for Breach of the Duty of Care}

Section 102(b)(7) of the Delaware Corporations Code ${ }^{\mathbf{1 8 1}}$ is closely tailored to exempt directors from negligence liability alone. ${ }^{182}$ Because it is an enabling statute, Section 102(b)(7) appears innocuous at first glance. Under the statute, a majority of the original incorporators may insert a liability-limiting clause into the certificate of incorporation prior to any receipt of payment for its stocks, ${ }^{183}$ or a majority of shareholders may adopt such a provision thereafter. ${ }^{184}$ Despite the democratic appeal of allowing the members of a corporation to decide for themselves whether to limit directors' liability, the Delaware legislature has not considered fully how completely the parties may avail themselves of the power granted them. It is now possible for shareholders to completely exempt their directors from liability even for gross negligence. In light of the important compensatory and deterrent functions of the duty of care, however, a legislatively-prescribed minimum level of liability below which the parties may not go is imperative. ${ }^{\mathbf{1 8 5}}$

The importance of the compensatory and deterrent functions of the duty of care is highlighted in circumstances similar to those in Francis v. United Jersey Bank. ${ }^{188}$ No one can seriously deny that inactive, or "figurehead," directors are a mockery of corporate governance. Yet, Delaware's liability-limiting provision opens the floodgates for "dummy directors" to infiltrate corporate boardrooms. As evidenced by

181 See supra note 11.

182 The drafters of the provision stated that "[c]harter provisions enacted under [Section 102(b)(7)] can, at most, absolve directors of liability for negligence, including gross negligence." Black, Jr. \& Sparks III, supra note 63, at 312.

183 See Del. CODE ANN. tit. 8, §§ 101, 102(b)(7), 241 (1983 \& Supp. 1986).

184 See Del. Code AnN. tit. 8, $\$ 242$ (1983); $q f .42$ Pa. Cons. Stat. Ann. $\S 8364$ (Purdon Supp. 1987):

(a) General Rule.-Whenever the bylaws of a corporation by a vote of the shareholders or members so provide, a director of a business corporation . . . shall not be personally liable for monetary damages as such for any action taken, or any failure to take any action, unless:

(1) the director has breached or failed to perform the duties of his office under section 8363 (relating to standard of care and justifiable reliance); and

(2) the breach or failure to perform constitutes self-dealing, willful misconduct or recklessness.

188 See supra notes $114-53$ and accompanying text.

18687 N.J. 15, 432 A.2d 814 (1981). For a discussion of Francis, see supra text accompanying notes $33-39$. 
the case law, ${ }^{187}$ market-based deterrents are not enough to stamp out Francis-type breaches of duty. Sadly, Delaware-type provisions allow the law to turn its back on those shareholders and other interested parties who suddenly find their investments frittered away by irresponsible boardroom "ornaments."188

The Delaware provision leaves unaffected a director's liability for: 1) breach of the duty of loyalty; 2) acts or omissions not in good faith or which involve intentional misconduct or a knowing violation of law; 3) unlawful payment of dividends or unlawful stock purchases or redemptions; and 4) transactions involving improper personal benefit. ${ }^{180}$ This raises the possibility that, in many cases, plaintiffs will simply recharacterize their claims and tailor them to fit one of the excepted categories. A likely category is the duty of loyalty, because "there is overlap between the elements of the two duties [of care and loyalty] and it may well be in many cases that the facts will be malleable enough to fit into one rubric as well as the other."190 It is unclear, however, how many duty of care actions will be brought under a duty of loyalty theory because the latter may represent a more difficult legal theory under which to litigate. ${ }^{191}$ Professor Clark has stated that a closer analysis of duty of care cases reveals that "directors were actually being sued . . . for a violation of their fiduciary duty of loyalty,"192 and that the courts" "twisted reasoning toward the conclusion that there was a violation of the duty of care was simply a way of giving the plaintiff[] a break . . . where equity seemed to require it." ${ }^{193} \mathrm{He}$ suggested that in duty of loyalty cases, proof of breach is more difficult and evidence harder to obtain. ${ }^{194}$ Thus, the Delaware provision probably will have the desired effect of suppressing negligence-based litigation.

The Delaware provision also leaves injunctive remedies unaffected, as it speaks solely of "monetary damages."19s Obviously, this is no comfort to those who already will have been injured by director negligence because they were unable to stop the harmful transaction before its con-

${ }^{187}$ See supra notes $148-51$ and accompanying text.

188 See supra note 39 and accompanying text.

189 See Del. Code ANN. tit. 8, § 102(b)(7)(i)-(iv) (1983 \& Supp. 1986).

190 Brown \& Davis, Indemnification of Directors and Officers and Limitations on Director Liability, 18-2 INST. ON SEC. REG. 117, 152-53 (1986); see also Note, supra note 89, at 668-69 ("As the duty of care wanes, the duty of loyalty waxes.").

191 See R. GLARK, supra note 18, \& 3.4 (citing Litwin v. Allen, 25 N.Y.S.2d 667 (Sup. Ct. 1940)).

${ }_{182}$ Id. $\$ 3.4$ (emphasis deleted).

193 Id.

194 Id.

195 Del. Code ANN. tit. 8, § 102(b)(7) (1983 \& Supp. 1986); see also Black, Jr. \& Sparks III, supra note 63, at 312 (reiterating that the Delaware law addresses only monetary damages). 
summation. In this respect, "[n]onfinancial penalties . . . have only limited applications and thus cannot serve as an adequate substitute for financial liability, in part because due care suits typically arise well after the event." 188 Injunctive remedies are inadequate for a more fundamental reason as well: their lack of deterrence value. Directors can act without fear of individual liability, because all that the courts can do is stop or rescind the offending transaction. Thus, having personally lost nothing, the director is not deterred from trying a similar scheme again. ${ }^{197}$ This problem especially is aggravated in situations in which market deterrents do not strongly affect directorial behavior. ${ }^{198}$

The deterrent value of the duty of care is compromised even further, or lost altogether, when a corporation elects totally to eliminate liability. For that reason, the ALI recommends that "a charter amendment should leave a minimum level of liability intact"; ${ }^{189}$ otherwise the duty of care would fail in its essential purpose. State legislatures, therefore, in order to preserve the fundamental deterrent value of the duty of care, should not allow that duty to become optional. ${ }^{200}$

When confronted with charter provisions under Section 102(b)(7), courts should scrutinize them intensely, especially if any of the following factors are involved: 1 ) the liability provision was part of the original certificate of incorporation; 2) the provision totally eliminates liability; or 3) the challenged transaction affects the shareholders' "ownership claims."

The first factor takes into account whether investors had adequate notice of an exculpatory provision adopted prior to any public offering. ${ }^{201}$ This notice concern, however, is limited by whether reasonable means existed by which to give notice. One commentator suggests that contracts of adhesion principles also would be implicated in such a

108 ALI DRAFT No. 6, supra note $14, \S 7.17$ reporter's note 2.

197 See Wiggins, Delaware's DEO Liability Law: A "Windfall" for Directors, Legal Times, Aug. 18, 1986, at 11, col. 1 (stating that the potential for liability is a necessary deterrent to negligence and bad faith).

198 See supra text accompanying notes 149-53.

100 ALI DRaFT No. 6, supra note $14, \S 7.17$ comment d(3).

200 The difficulty arises in ascertaining the optimal "minimal level" of liability. This is discussed in connection with the ALI proposal. See infra notes 216-31 and accompanying text.

${ }^{201}$ See Coffee, supra note 2, at 826:

[L]ittle confidence should be placed on limitations adopted in the original certificate of incorporation to the extent that they immunized corporate officials from any liability to shareholders for due-care violations. At this point, traditional contract principles, such as those applicable to contracts of adhesion, would become relevant, and a sophisticated court could use them to reach a just result under the circumstances. 
case. $^{202}$

The second factor involves public policy and statutory construction issues. The Delaware legislature could have abolished the duty of care much like Virginia, but it chose not to do so. The Delaware legislature leaves the decision totally up to the shareholders and even then, only in monetary damage cases. This perhaps illustrates the Delaware legislature's reluctance to totally abandon the duty of care and the important deterrence function associated with it. Yet, total elimination of duty of care liability would essentially render that doctrine and its goal of deterrence meaningless. Thus, a charter provision accomplishing this undesirable goal should not be given effect because it offends public policy ${ }^{203}$ or equity principles. ${ }^{204}$

This argument is bolstered by showing the third factor, that "ownership claims," gested that the differentiation between "enterprise issues" and "ownership claim issues" helps explain duty of care jurisprudence. He asserts that "ownership claim issues" receive more critical judicial attention because they involve a drastic change in the shareholders' role as "owner," potentially "sever[ing] a shareholder from his chosen investment." 206 Thus, in cases involving sale of the company or cessation of the corporate entity, questionable directorial behavior should be judged critically despite liability-eliminating provisions.

A valid charter provision, however, will most likely withstand such attacks, thus leaving the litigant to challenge whether in fact the provision was adopted validly. The ALI suggests that "judicial review of exculpatory charter amendments should look to the process by which the amendments were adopted to determine if a fiduciary relationship was abused."207 Thus, judicial review is warranted when "misleading or incomplete disclosure was made with respect to [a charter provision's] adoption or renewal."208 Federal securities laws also are relevant

202 Id.

${ }^{203}$ See ALI Draft No. 6, supra note $14, \S 7.17$ comment d(3) (discussing public policy grounds for invalidating a charter amendment).

204 See W. CARY \& M. EISENBERG, supra note 19, at 1636 ("[C]/harter amendments normally will be reviewable on the ground of fairness.").

${ }^{205}$ See Manning, supra note 46, at 5 (distinguishing between "enterprise issues"- normal business decisions by the board in the course of operations that eventually affect the value of stock-and "ownership claim" issues-unexpected board actions which directly affect the continued existence of an owner's investment in a chosen firm).

${ }^{208}$ Id. at 5-6 ("[N]one of us reacts well to receipt of a letter saying, "This will inform you that $I$ have just sold your house. Check is enclosed." ").

${ }^{207}$ ALI Drafr No. 6, supra note $14, \S 7.17$ comment e.

208 Id. 
in this regard. ${ }^{200}$

A special problem arises when the litigant is a party operating outside of the corporation. Third parties, such as a corporation's bondholders, ${ }^{210}$ insurance policy holders, ${ }^{211}$ creditors, ${ }^{212}$ or parties to a contract, ${ }^{\mathbf{2 1 3}}$ can bring duty of care litigation. The United States Supreme Court broadly asserted that the "standard of fiduciary obligation is designed for the protection of the entire community of interests in the corporation-creditors as well as stockholders."214 Representation of third party interests is often found in cases involving a bankrupt corporation, as in Francis $v$. United Jersey Bank, in which the bankruptcy trustees sued the directors for breaches of their duty of care. The Francis court held the directors liable for the losses of the clients of a bankrupt reinsurance brokerage firm. The court, focusing on the special nature of the relationship between the parties, opined:

The hallmark of the reinsurance industry has been the unqualified trust and confidence reposed by ceding companies and reinsurers in reinsurance brokers. Those companies entrust money to reinsurance intermediaries with the justifiable expectation that the funds will be transmitted to the appropriate parties. ...

. . That trust relationship [gives] rise to a fiduciary duty to guard the funds with fidelity and good faith. ${ }^{215}$

It would be unreasonable to bind third parties to liability-limiting provisions for several reasons. First, these parties have no say in the adoption or maintenance of such provisions. Second, binding third parties to such provisions would impede business efficiency by requiring that potential creditors check for such a provision in the certificate of incorporation of every customer with whom it intends to deal. Third, the purpose of the Delaware provision, to attract directors into service, would be irrelevant in the case of a bankrupt corporation, a situation

${ }^{200}$ See, e.g., 15 U.S.C. $\S 78$ n(e) (1982) (enabling the Securities and Exchange Commission to regulate untrue statements or omissions).

${ }_{210}^{210}$ See, e.g., Dinsmore v. Jacobson, 242 Mich. 192, 218 N.W. 700 (1928).

${ }_{211}$ See, e.g., Rowen v. Le Mars Mut. Ins. Co., 282 N.W.2d 639 (Iowa 1979); Doyle v. Union Ins. Co., 202 Neb. 599, 277 N.W.2d 36 (1979).

${ }_{212}$ See, e.g., Pepper v. Litton, 308 U.S. 295 (1939); In re Happy Time Fashions, Inc., 7 Bankr. 665 (Bankr. S.D.N.Y. 1980); Francis, 87 N.J. 15, 432 A.2d 814; Neese v. Brown, 218 Tenn. 686, 405 S.W.2d 577 (1964).

${ }_{213}$ See, e.g., Mobridge Community Indus., Inc. v. Toure, Ltd., 273 N.W.2d 128

(S.D. 1978).

${ }^{214}$ Pepper, 308 U.S. at 307.

215 Francis, 87 N.J. at $37-38,432$ A.2d at 825. 
most likely to involve third-party litigants, especially when the firm is being liquidated. Further, in the bankruptcy scenario, one can argue that the law should look less sympathetically upon directors of a bankrupt firm when the directors' misbehavior contributed to the company's downfall.

In sum, section 102(b)(7) of the Delaware Corporations Code is a more sophisticated solution to the problem facing directors today; however, it remains unsatisfactory because it allows for the total elimination of duty of care liability, thus eliminating that duty's deterrent value. Moreover, the Delaware provision may open a Pandora's box of directorial misbehavior in situations in which market deterrents have little effect because it is in precisely those situations that the duty of care has been most useful and effective in acting as a deterrent. Other states, therefore, should consider placing a minimum level of directorial liability to ward off this possibility. This fine-tuning of liability levels and the novel proposal of the ALI will be discussed next.

\section{Liability Fixing and the ALI "Economic Benefits" Formula}

The current version of the ALI proposal concerning the limitation of damages for due care violations 216 $^{12}$ lies liability to the "economic benefits" received by the director. Unlike the Delaware law, the ALI version does not allow the corporation to eliminate completely duty of care liability; still, it has a similar defect in that no minimum level of liability is prescribed explicitly. ${ }^{217}$

The first version of the ALI liability limiting provision set out both a maximum and minimum amount of damages that could be assessed for a breach of the duty of care, ${ }^{218}$ it also included an alternative

216 See supra note 14.

217 See ALI Draft No. 6, supra note 14 , at $\S 7.17$.

218 American law Institute, Principles of Corporate Governance and Structure: Restatement and Recommendations $\S 7.06$ (Tent. Draft No. 1, 1982) provides in part:

d. Maximum Damages: Eligibility for Ceiling on Liability for Ordinary Negligence: The ceiling on liability determined by the court under $\$ 7.06(\mathrm{e})$ shall limit the maximum liability for monetary damages in respect of a violation of a duty ... by a present or former . . . director or corporate fiduciary, who in each case can establish the following factors:

(i) the conduct or nonfeasance resulting in such defendant's liability did not involve knowing misconduct, or recklessness, or otherwise surpass the level of ordinary negligence;

(ii) the defendant did not improperly benefit from the transaction nor act so as to subordinate the interests of the corporation to those of such defendant. . . .

e. Determination of Ceiling. The court shall select and fix a ceiling on the liability for monetary damages of each individual defendant who qualifies 
formula tied to "gross compensation" for certain defendants. ${ }^{218}$ This fixed approach, however, was problematic, because it was "necessarily arbitrary and lack[ed] a conceptual foundation."220 Thus, the ALI retreated to a full recovery formula in a later draft. ${ }^{221}$ In the current draft, the conceptual void has been filled by a contract rationale. Commentary to the present version provides that "[b]ecause the relationship between a director or officer and the corporation is consensual in nature, the theory of contract damages affords an alternative rationale by which to determine the damages for a violation of the duty of care, even when the loss is foreseeable."222

The present ALI version, consequently, appears well-suited to accomplish its proffered goals of fairness, a reduction of unduly riskaverse behavior, a reduction in the cost of insurance, and the stabilization of judicial implementation of the duty of care. ${ }^{223}$ Importantly, preserving the deterrent function of the duty of care was not cited as a rationale for the ALI formulation. The commentary does acknowledge that some minimum level of liability should be left intact to serve the "essential purpose" of the duty of care, but the ALI provision "does not specify with precision what the minimal level of liability should be."224

under 7.06(d) that is within the following applicable ranges:

(i) in the case of a director who, at the time of the events giving rise to the action, was not otherwise an employee or officer of the corporation in whose name the action is brought, . . . the ceiling shall not exceed (A) $\$ 200,000$, nor fall below (B) $\$ 50,000$; and

(ii) in the case of any other defendant whose liability is based upon a duty owed to the corporation as an employee or as a corporate fiduciary, the range shall not exceed (A) the higher of (1) $\$ 200,000$, or (2) twice such defendant's gross compensation from the corporation . . . , nor fall below (B) such defendant's gross compensation from the corporation for the same year. . : .

In determining the ceiling to impose, within the foregoing ranges, the court may consider any factor that, . . . bears on the responsibility of the defendant for the loss in question. ...

218 Id. at $\S 706(\mathrm{e})$.

220 Coffee, supra note 2 , at 822 .

221 Principi.es of Corporate Governance: Analysis and RecommendaTIONS $\S 7.16$ (Discussion Draft No. 1, 1985) provides:

(a) Except as otherwise specifically provided, a defendant who violates the standards of conduct set forth in Parts IV and V should be liable for all losses to the corporation or its shareholders legally caused by the violation, and for any other gains derived by him to the extent necessary to make full restitution.

But see id. $\S 7.16$ reporter's note 14 (noting an unapproved alternative formula that would limit damages based on the defendant's compensation).

222 ALI DRAFT No. 6, supra note 14, § 7.17 comment $\mathrm{d}(2)$; see also Coffee, supra note 2, at 823 (discussing various contract solutions to a duty of care violation).

${ }^{223}$ ALI DRAFT No. 6, supra note 14, $\$ 7.17$ comment c.

224 Id. $\$ 7.17$ comment d(3). 
The commentary states that "[i]t seems reasonable to hold such officials liable for the economic benefits received from the corporation for services that they failed to provide adequately."225

This Comment, however, argues that it would be unreasonable to limit plaintiffs' recovery to the economic benefits received by the director when a great disparity exists between those benefits and the economic harm suffered by the plaintiffs. Indeed, if the director did not receive any benefits, the plaintiffs would recover nothing. Unfortunately for the claimant, inadequacy of recovery cannot be used as a rationale for boosting damages under the ALI formula. ${ }^{226}$ Thus, the ALI ceiling on recovery should give way when a director's egregious conduct renders that recovery insignificant. ${ }^{227}$

A liability minimum also is needed to offer at least partial compensation to injured shareholders and to deter the negligent behavior of directors who receive nothing from the corporation but also give nothing back. Unfortunately, setting a liability minimum in terms of dollars is a frustrating task, and such an attempt would be conceptually undesirable in any case because of its arbitrariness. ${ }^{228}$ Instead, a simple proviso should be added at the end of Section 7.17(a) of the current ALI proposal. This proviso would read, "provided that when damages would equal zero under this rule, or would likewise be insignificant in view of the extent of the director's breach of her duty and of the injury caused thereby, positive or additional damages should be assessed [to effectuate the essential purpose of Part IV, setting forth duty of care, without offending the purpose of this liability-limiting rule]."

Through this modification, Section 7.17(a) should realize more fully the provision's apparent intent to preserve the deterrent value of the duty of care. This intent can be inferred by reading the carefully drafted requirements, all of which must be met $^{229}$ before a defendant can take advantage of the provision's liability shield. Two of the requirements, a lack of conscious disregard of one's duty (Section $7.17(\mathrm{a})(3))$ and a lack of a sustained and unexcused pattern of inattention (Section 7.17(a)(4)), cover much of the market-fringe area discussed in Section IIB, in which market deterrence is ineffective and duty of care deterrence is dominant. ${ }^{230}$ Minimum liability levels, how-

228 Id.

${ }^{228}$ Id. $\S 7.17(\mathrm{a})$.

${ }^{227}$ See Coffee, supra note 2, at 799 (arguing that the ceiling should be "porous" in situations of knowing legal violations or gross recklessness).

${ }^{228}$ See id. at 822.

229 See ALI DRAFT No. 6, supra note 14 , at $\S 7.17$ (a)(1)-(4).

2so Professor Coffee wrote, to the same effect, that the requirements "essentially cover the limited number of decisions, such as Francis v. United Jersey Bank, in which 
ever, are still necessary in order not to foreclose the traditional duty of care analysis. ${ }^{231}$ Therefore, the ALI "economic benefits" rule, with the above modification, is best suited to resolve the "director crisis" afflicting today's corporations, because it preserves the fundamental values inherent in the duty of care.

\section{CONCLUSION}

This Comment has analyzed the major factors contributing to the recent exodus of directors from the boardrooms of corporate America: the alleged resurgence in duty of care liability and the perverse inflation in the D\&O insurance market. A close evaluation of the two factors revealed, however, that they do not provide adequate justification for mass hysteria by directors. Many legislatures confronting the grave problem of depleted corporate boards believed that a curtailment of allowable damages in duty of care litigation was the best way to solve this problem. Those legislatures, however, should have acted in a way that preserved, not sacrificed, the compensation and deterrent values of the duty of care. While these values are of less consequence in mainstream corporate America, they are extremely important in situations wherein market forces ordinarily influencing directorial behavior hold little sway. ${ }^{232}$ Moreover, the duty of care embodies a foundational deterrent value, a bare minimum standard of care above which marketbased standards may fluctuate.

In light of the foregoing discussion, this Comment concludes that both the Indiana and Virginia approaches to the problem, i.e., lowering the standard of conduct, are inappropriate because of either debilitating uncertainty or draconian overbreadth. The Delaware provision, while more sophisticated, carries with it the danger that the deterrent value will be bargained away completely. The "economic benefits" formula set forth by the ALI, with a modification suggested by this Comment designed to avoid the problem inherent in Delaware's approach, is the most appropriate vehicle with which to deal with directorship problems. Not only does it to help alleviate those problems, but it also operates without unduly diluting the compensatory and deterrent values underlying the duty of care.

courts have actually imposed substantial liability." Coffee, supra note 2 , at 820 .

${ }^{231}$ See supra note 119 and accompanying text.

232 See supra text accompanying notes 136-60. 